\title{
LEGISLATIVE CONSTITUTIONAL INTERPRETATION
}

\author{
NEAL KUMAR KATYAL $\dagger$
}

\section{INTRODUCTION}

This is an Essay about "the how" of constitutional interpretation. Much attention has been devoted to the question of how the Constitution is interpreted in courts. Rather little attention has been devoted to the question of how the Constitution is interpreted elsewhere in the government. The Constitution tells us that Congress, the President, and state legislators and courts must adhere to its terms, but it does not tell us how much interpretive power each actor should have, nor does it prescribe rules for each actor to use when interpreting the text. I argue that constitutional interpretation by Congress is, and should be, quite different from constitutional interpretation by courts. In so doing, I combine insights from political scientists about the ways Congress operates with insights from constitutionalists who fear open-ended interpretation.

Congressional interpretation is a recurring problem in constitutional law. In the last four years, momentous events have forced us to rethink how Congress should approach the task. In 1997, the Supreme Court struck down the Religious Freedom Restoration Act (RFRA) on the ground that Congress could not expand constitutional rights through ordinary legislation. ${ }^{1}$ The next year, Congress was required to make a judgment about the meaning of the phrase "high Crimes and Misdemeanors" in President Clinton's impeachment trial. ${ }^{2}$ Last year,

Copyright $(\subseteq 2001$ by Neal Kumar Katyal.

$\dagger$ Associate Professor of Law, Georgetown University Law Center. For helpful comments, I am thankful to participants in a Georgetown faculty workshop, as well as to Akhil Amar, Rachel Barkow, Neal Devins, Jeffrey Rosen, and Miriam Vogel. The Essay is dedicated to my sister, Sonia.

1. City of Boerne v. Flores, 521 U.S. 507, 535-36 (1997).

2. Consider, for example, one representative's assumption that congressional constitutional methodology should track the Court's:

I am absolutely amazed at the liberal and loose interpretation of the constitution that 
the Supreme Court declared unconstitutional a statute that excused law enforcement officials from providing the four warnings specified in Miranda v. Arizona. ${ }^{3}$ A separate decision announced the belief that only the Court has the power to define the meaning of the Fourteenth Amendment. ${ }^{4}$ More recently, in the wake of the 2000 presidential election, a wide debate ensued about the contours of the right to vote, Congress's role in counting electoral votes, and the meanings of the Twelfth and Fourteenth Amendments. ${ }^{5}$ Each of these events challenges us to consider whether Congress should use the techniques of constitutional interpretation that are so familiar to courts.

My conclusion is that because of its unique institutional features, Congress should interpret the text in ways the courts should not. For example, I suggest that Congress should take popular values and beliefs into account when formulating constitutional principles. I also suggest that the virtues and vices of adhering to precedent are somewhat different for legislative precedent than for judicial stare decisis. The structural variances between the courts and Congress can be analyzed profitably to develop a theory of interbranch interpretation that takes advantage of the comparative strengths of each branch. The institutional differences between the branches can be a source of richness, rather than a constitutional weakness.

The analysis proceeds in three parts. Part I analyzes the Senate's advice and consent power. I suggest that the Senate should, in some instances, use its ability to take the pulse of the nation to inform its constitutional judgments, and that the Senate should seek to reify these pronouncements in Supreme Court confirmation hearings. I argue that the Senate should use confirmation hearings to instruct not only nominees, but currently sitting Justices as well, about ways to

I'm hearing from conservatives. Usually, progressives are accused of loose interpretation and usually conservatives are considered to have strict interpretation of the constitution and law. But sitting in this committee, I have witnessed the most-the loosest interpretation of the Constitution, as my colleagues on the other side of the aisle have dealt with the meaning of high crimes and misdemeanors.

144 Cong. REC. H11,774 (daily ed. Dec. 12, 1998) (statement of Rep. Waters); see also Cass R. Sunstein, Impeaching the President, 147 U. PA. L. REV. 279, 281 (1998) ("A striking aspect of the debate over impeachment between 1997 and 1999 has been its insistently originalist character.").

3. United States v. Dickerson, 530 U.S. 428, 441-42 (2000).

4. Kimel v. Fla. Bd. of Regents, 528 U.S. 62, 81 (2000) ("Congress cannot 'decree the substance of the Fourteenth Amendment's restrictions on the States.'... The ultimate interpretation and determination of the Fourteenth Amendment's substantive meaning remains the province of the Judicial Branch.") (quoting City of Boerne, 521 U.S. at 536).

5. See Bush v. Gore, 121 S. Ct. 525 (2000). 
approach constitutional issues. The Senate can criticize decisions, or, more interestingly, bless decisions that are not firmly grounded in the text, history, or structure of the Constitution. As part of the analysis, I propose a new way of thinking about Bruce Ackerman's dualist constitution. In Part II, I consider Congress's ability to change constitutional pronouncements through ordinary legislation. This part develops an argument explaining why Congress can enact laws that call into question certain Supreme Court decisions. The Court has recently been hostile to Congress as a constitutional interpreter, particularly in its recent Section 5 jurisprudence; I suggest that these cases should be reconsidered. ${ }^{6}$ In Part III, I illustrate the differences between interpretive methodologies, using impeachment as an example. Because the Senate sits as a "court" of impeachment, some might suppose that impeachment is the paradigm case where the courts' and Congress's constitutional methodologies should be symmetric. I argue that it should not be, however, because the courts' and Congress's structural constraints differ substantially.

\section{ADVICE \& CONSENT}

One of the hardest questions in constitutional law has been what should judges do when the text, history, and structure do not provide clear guidance in a given case? One answer is that judges must not venture beyond these three interpretive methodologies. Any interpretive gloss that judges place upon the Constitution, the answer goes, will reflect their own biases, not those of the people. ${ }^{7}$ The problem with this approach, as many have noted, is that few people really take

6. This Essay brackets constitutional interpretation by the President because it raises a host of different issues. Presidents face elections once every four years and differ substantially in their accountability to the public. Similarly, I do not consider how state courts and state legislators should interpret the Constitution. Because state judges often are elected, their accountability may serve as an anchor that enables a broader interpretive methodology than that used by federal courts. State courts might therefore be suited for interpretation that takes account of popular values. However, such interpretation by state courts and state legislatures raises the specter that they will use interpretation to frustrate the national will. See McCulloch v. Maryland, 17 U.S. (1 Wheat.) 316, 401-03 (1819). Because of the substantial complexity of these issues, they will not be addressed in this short Essay.

7. Cf. Planned Parenthood v. Casey, 505 U.S. 833, 944, 952 (1991) (Rehnquist, C.J., dissenting) ("We believe that Roe was wrongly decided .... Nor do the historical traditions of the American people support the view that the right to terminate one's pregnancy is 'fundamental."”); see also Michael H. v. Gerald D., 491 U.S. 110, 127 n.6 (1989) (using historical traditions to interpret the Due Process Clause); RoBert H. BORK, THE TEMPTING OF AMERICA 3-5 (1990) (outlining an historical approach to judicial interpretation); ANTONIN SCALIA, A MATTER OF INTERPRETATION 38, 133 (1997) (arguing that the idea of a "living Constitution" ignores the Constitution's “original meaning”). 
it seriously. The Constitution's expansive clauses were not meant to be anachronistic and brittle; they were designed as the broad outlines of a structure of governance that was meant to endure. ${ }^{8}$ For the Constitution to be translated from the eighteenth century into the twentyfirst century, a variety of interpretive judgments must be made that require the application of supposedly "timeless" principles to current events. Does violence against women substantially affect interstate commerce? ${ }^{9}$ Is the electric chair "Cruel and unusual?" constitutional evolution has been stressed in key legislative events for the past two centuries, such as during the hearings on reauthorization of the Bank of the United States ${ }^{11}$ and the enactment of the Sherman Antitrust Act. ${ }^{12}$ When these present-day judgments are made by unelected and unaccountable judges, the countermajoritarian difficulty looms large. ${ }^{13}$

Legislative constitutional interpretation provides one avenue for reconciling what have generally been thought to be two incompatible goals: a living Constitution and a democratic government. ${ }^{14}$ The question addressed in this part is how to create a theory of constitutional interpretation that permits endurance but is attentive to the countermajoritarian difficulty. I shall argue that Congress, not the Court, is often best situated to make the judgments necessary to create a Constitution of relevance to Americans today. In the face of contestability over text, history, and structure, if a constitutional question raises an

8. For a constitution to "contain an accurate detail ... would partake of the prolixity of a legal code, and could scarcely be embraced by the human mind" and would probably never be understood by the public." Instead, its "nature ... requires[] that only its great outlines should be marked." McCulloch, 17 U.S. at 407.

9. United States v. Morrison, 529 U.S. 598 (2000).

10. Bryan v. Moore, 744 So. 2 d 452 (Fla. 1999), cert. granted, 120 S. Ct. 394 (1999), cert. dismissed as improvidently granted, $120 \mathrm{~S}$. Ct. 1003 (2000).

11. In commenting on the constitutionality of the Bank of the United States, Senator Crawford stated: "We are, when acting today, not to inquire what means were necessary and proper twenty years ago, not what were necessary and proper at the organization of the Government, but our inquiry must be, what means are necessary and proper this day." SENATOR WILLIAM H. CRAWFORD, HISTORY OF CONGRESS 143 (1811).

12. Senator Sherman, in defending the constitutionality of the Antitrust Act, argued that many of the powers of the federal government "have remained dormant, unused, but plainly there, awaiting the growth and progress of our country.... While we should not stretch the powers granted to Congress by strained construction, we can not surrender any of them; they are not ours to surrender." 21 CONG. REC. 2461 (1890) (statement of Sen. Sherman).

13. AleXander Bickel, The Least Dangerous Branch 16 (1962).

14. For purposes of this Essay, I am assuming that both of these goals are desirable ones. There are many reasons to believe that the countermajoritarian difficulty is not nearly as great a problem as Bickel supposed, and many reasons to be against a living Constitution. Such matters are outside the scope of this Essay. 
issue of popular values or broad factual assessments, Congress may be better than the Court at making this determination. ${ }^{15}$ Especially when text, history, and structure are ambiguous, Congress's interpretations as a politically accountable actor will be useful. One powerful vehicle for making these judgments is through the Senate's advice and consent power. This power is exercised both ex ante, by telling the President the type of candidate who could get confirmed (textually, "Advice") and ex post, by voting down nominees who do not share a particular constitutional interpretation (textually, "Consent"). ${ }^{16}$

\section{A. A Proposal}

The fear of countermajoritarianism has led many to insist on strict construction of the Constitution's text. This fear has strong implications for the way Article III courts should conduct their interpretation, but it does not necessarily apply to situations where politically accountable actors are doing the interpreting. Public accountability imparts a subtle elasticity to congressional interpretation, and this feature makes it desirable for Congress to interpret the Constitution in ways that courts should not.

The key, and often overlooked, structural distinction between courts and Congress is that the latter is well-situated to understand the views of the people. Members of Congress are up for reelection every two or six years. ${ }^{17}$ Because they attend constituent "meet-andgreets," fundraisers, and a host of other political functions, members of Congress are able to infuse their judgments with the views of those they represent. Our Constitution presumes that the government's key decisions will be made by the people, and its legitimacy is grounded in the consent of the governed. Democratic participation is not only an inherent good; it also provides a mechanism to police transgressions by elected officials. When lawmakers interpret the Constitution in unwarranted ways, they can be voted out of office. On the Court, by contrast, life tenure and salary guarantees insulate the Justices from reprisal. The Justices mingle with a tiny number of people and have little incentive to understand life beyond the cloister where they work. The countermajoritarian difficulty surfaces in Court decisions

15. If a particular congressional interpretation restricts individual rights, however, there are reasons not to award that determination supremacy. See infra notes 19, 68-69, 120-23 and accompanying text.

16. Consent, however, may be a more powerful mechanism because the eyes of the people are drawn more to a confirmation hearing. See infra note 147 and accompanying text.

17. U.S. CONST. art. I., $\S \S 2-3$. 
because the Justices have little competence at discerning popular views and no accountability for the judgments they render. ${ }^{18}$ For those worried about the vigor of popular rule in America, there is much to fear from judicial interpretation. Therefore, judges should labor under special interpretive guidelines precisely because they lack the accountability of members of Congress.

Because of these structural differences, I propose that the Senate structure Supreme Court confirmation hearings in a way that permits deliberation on the hard constitutional questions where text, history, and structure do not provide a complete answer. In the hearings, senators should strive to reach consensus on these difficult issues. The Senate's advice and consent power provides a vehicle for Congress to breathe life into the Constitution, even when (indeed, because) courts are strictly constrained. Under this proposal, however, the Court would retain its power to decide whether to heed the Senate's interpretive lessons.

There is, however, one important constraint: I believe that the Court should accord a presumption of interpretive correctness to the Senate only if the Senate's interpretation increases individual constitutional rights and only if there was serious deliberation in the chamber about the constitutional right at stake. The reasons for this limitation will be outlined later. Suffice it to say for now that a salient feature of the Constitution is its commitment to individual rights (this commitment is reflected in the Constitution's structure, which creates a rights-protecting asymmetry permitting any branch to veto a decision that changes the status quo in a way that undermines individual

18. Michael W. McConnell, A Moral Realist Defense of Constitutional Democracy, 64 Chi.-Kent L. ReV. 89, 105-06 (1988):

Judges are grossly unrepresentative of the population. All are lawyers, most are middle-aged or older, all are upper-middle class or above, most are white males, most are secular and skeptical in their philosophical orientation, in common with the professional elite of this country. Rather than natural right, judges are more likely to impose upon us the prejudices of their class.... They are dependent for information and ideas upon people with an inherent professional axe to grind. They are carefully insulated from the real world. Their caseloads (especially the Supreme Court's) are overwhelming. They have little time for even the most important of cases, and it is the rare Supreme Court Justice who can keep up with more than a negligible sampling of the poetry, science, economics, literature, philosophy, theology, and history that should inform an expositor of moral reality. Their sole assistants are bright young things just out of law school. Perhaps most importantly, judges are irresponsible in the most fundamental sense: they are not accountable for the consequences of their decisions and ordinarily are not even aware of them. Power without responsibility is not a happy combination. 
rights). ${ }^{19}$ My goal, therefore, is to balance the Constitution's commitment to individual rights against two other structural values-accountability and constitutional evolution.

This theory of interpretation emphasizes that courts are poorly suited to reading shifts in popular will. They are removed from the people, unelected, and have little incentive to understand popular mores-features highlighted by strict constructionists. Congress, on the other hand, frequently makes determinations as to shifts in popular opinion, beliefs, and ideals. Because of Congress's structural superiority in these tasks, it should take a larger role in interpreting those clauses of the Constitution that are meant to evolve over time.

This is not the proper time and place to get into a debate over what those clauses may be. Suffice it to say that if any clauses should be subject to a living and evolving interpretation, it is almost always preferable that the legislature be the branch making these choices. For example, it is commonplace for liberals and conservatives alike to recognize that the Eighth Amendment's Cruel and Unusual Punishments Clause has a meaning that grows with time to reflect "the evolving standards of decency that mark the progress of a maturing society.", ${ }^{20}$ Indeed, the Court often states that the meaning of "due process" depends on contemporary values. For example, in the recent Lewis case the Court decreed that "the threshold question" in a due process challenge to executive action was whether the conduct was "so outrageous[] that it may fairly be said to shock the contemporary conscience." ${ }^{21}$ Such words can be read as invitations for legislative interpretation of the Constitution-not simply instructions to courts, which, after all, are comparatively ill-suited to make such broadbased and final societal determinations.

19. See infra notes $68-69,120-23$ and accompanying text.

20. Rhodes v. Chapman, 452 U.S. 337, 346 (1980) (quoting Trop v. Dulles, 356 U.S. 81, 101 (1958)); see also Stanford v. Kentucky, 492 U.S. 361, 370-71 (1988) (looking to whether states authorize capital punishment of sixteen- and seventeen-year-olds to determine whether the practice violates the Eighth Amendment); Coker v. Georgia, 433 U.S. 584, 597-600 (1976) (looking to whether states authorize capital punishment for rape in analyzing an Eighth Amendment challenge); Estelle v. Gamble, 429 U.S. 97, 103 (1975) (holding that the Eighth amendment challenge requires examining whether a practice is "inconsistent with contemporary standards of decency").

21. County of Sacramento v. Lewis, 523 U.S. 833, 847 n.8 (1997); see also Parke v. Raley, 506 U.S. 20, 32-33 (1992) (looking to contemporary practice in resolving a due process challenge); Schad v. Arizona, 501 U.S. 624, 637 (1990) ("In translating [due process's] demands for fairness and rationality into concrete judgments about the adequacy of legislative determinations, we look both to history and wide practice as guides to fundamental values."); Burnham v. Superior Court of Cal., 495 U.S. 604, 630 (1989) (Brennan, J., concurring) (arguing that procedural rules, "even ancient ones, must satisfy contemporary notions of due process"). 
Courts are better equipped to decide the case before them than to issue ultimate pronouncements on the transformation of public values. Of course, the Senate has not always acted high-mindedly, and the risk remains that some of the interpretations it announces will be unprincipled. The Court has not always been principled either, though. And perhaps some of the Senate's reluctance to decide constitutional questions on the basis of principle arises from a feeling that the Court is deciding them. Placing more power in the hands of the Senate through advice and consent may help, not hinder, principled constitutional judgments. Solemn discussions about constitutional law during Supreme Court confirmation hearings may cause even the more political senators to rise above their baser motives.

In addition to the advantages derived from institutional competence, there are also accountability advantages to this course of action. This is the lesson contained in a key letter from James Madison to Spencer Roane. Madison criticized the Supreme Court for misinterpreting the Founders' views on nationalization. ${ }^{22}$ Madison believed that Congress should make its own constitutional judgments against nationalization due to its accountability. ${ }^{23}$ Congress could "abstain from the exercise" of such powers if it were convinced that the Court was wrong. If members of Congress made the wrong choice, "their Constituents ... can certainly under the forms of the Constitution effectuate a compliance with their deliberate judgment and settled determination. ${ }^{24}$ Madison recognized the possibility of dual tracks of constitutional interpretation, the possibility that both actors-courts and Congress-would analyze constitutional questions and abstain from decision if necessary. To Madison, accountability served to deter unpopular constitutional interpretations and to remove from power those who author them.

My proposed use of the advice and consent power would not permit Congress to rewrite the Constitution's text. After all, Article V explains that Congress cannot do that without observing certain formalities. Nor would it mean that Congress could substitute hasty and ephemeral political views for constitutional principle. Instead, the proposal suggests that Congress would perform that range of activities that judges have come to perform in the past several decades-ac-

22. Letter from James Madison to Spencer Roane (May 6, 1821), in 9 WRITINGS OF JAMES MADISON 1819-1836, at 55, 59 (Gaillard Hunt ed., 1st Am. ed. 1910).

23. Discussing the Court's nationalist decisions, Madison said that "there is as yet no evidence that they express the opinions of Congress or those of their Constituents." Id.

24. Id. 
tivities that move America away from an anachronistic Constitution. In particular, the Senate would abstract the views of the Founders and apply those ideals to contemporary life. In performing this role, the Senate should reflect intensely upon the constitutional vision of our Founders and consider how such beliefs bear on constitutional interpretation.

Consider an example. Supreme Court Justices regularly assume that Brown v. Board of Education ${ }^{25}$ is right, even if they are unsure why. Asymmetry about strict construction suggests an answer: Brown's legitimacy may be derived not from the opinion itself, but from the fact that the Senate has endorsed the opinion. This was made clear in the hearings of Robert Bork, where liberal and conservative senators all agreed that Brown was correctly decided. Consider, for example, the powerful speech by then-Senator Bill Bradley, who used the power of abstraction to justify Brown. Bradley called Judge Bork's views inconsistent with the struggle of racial minorities to "realize the promise of the Declaration of Independence "that all men are created equal, that they are endowed by their Creator with certain inalienable rights, that among these are life, liberty, and the pursuit of happiness.", ${ }^{26}$ The Senator exhorted Americans to "remember that the change begun by Brown versus Board of Education brought black Americans greater freedom and opportunity, but it also gave white Americans self respect." ${ }^{27}$ In essence, Bradley was updating a constitutional guarantee by reference to the ideals of the Founders and transplanting those ideals to a modern world. Other senators, including prominent Republicans, announced similar views. Senator Danforth remarked that "the Court must continue to safeguard important individual rights such as the right to racial equality protected by cases like Brown versus Board of Education. ${ }^{28}$ In other words, these senators were adopting the interpretive proposal put forth in the Brown decision and accepting the claims the decision made about the social science literature, that segregation by its nature is inferior and unequal (a view that the Court opposed in its earlier Plessy decision).

25. 347 U.S. 483 (1954).

26. 133 CONG. REC. S12,983 (1987) (statement of Sen. Bradley).

27. Id.; see also, e.g., 121 CONG. REC. 20,653 (1987) (statement of Sen. Cranston) (endorsing the view that "Bork and other critics of the Warren Court never bothered to point out that Plessy was a far greater distortion of constitutional 'intent' than Brown v. Board of Education").

28. 133 Cong. REC. 20,931 (1987) (statement of Sen. Danforth). 
Brown did not receive as much attention in the Bork hearings as it might have, in part because Judge Bork-seeing the writing on the wall-emphasized in his hearing that the decision was obviously right. His prepared statement claimed that "Brown, delivered with the authority of a unanimous court, was clearly correct and represents perhaps the greatest moral achievement of our constitutional law." ${ }^{29}$ (Bork's trajectory followed that of William Rehnquist at his confirmation hearings to be Chief Justice, where he disavowed a memorandum he had written as a Supreme Court law clerk that appeared to support segregated schools. ${ }^{30}$ ) The consensus in the Senate over Brown was such that three years later, during Justice David Souter's confirmation hearings, Senator Cranston remarked that " $\mathrm{t}]$ here is no question but that a nominee who would vote to overturn Brown ... or refuse to discuss that case would be rejected on the basis of the single issue of desegregation." $" 31$

29. Nomination of Robert H. Bork to be Associate Justice of the Supreme Court of the United States: Hearings Before the Senate Comm. on the Judiciary, 100th Cong. 108 (1989) (statement of Robert Bork); see also id. at 262 ("If the social change is mandated by a principle in the Constitution or in a statute, then the Court should go ahead and bring about social change. Brown v. Board of Education brought about enormous social change, and quite properly."); id. at 352 ("I have endorsed everything from Brown v. Board of Education on up."); id. at 285 (describing Brown as "politically controversial" but noting that "[b]y 1954, it was perfectly apparent that you could not have both equality and separation").

Not only the Senate, but the House too, was an active participant in the Bork hearings and Brown. E.g., id. at 3169 (statement of Rep. Conyers) ("But if Robert Bork had had his way, none of these decisions [including Brown] would have occurred and there would be no Black Caucus"); see also 133 CONG. REC. 24,344 (1987) (statement of Rep. Hayes) ("Judge Robert H. Bork by his record has never shown the least concern for working people, minorities, the poor .... We're one vote away from losing our most fundamental rights ...."). In addition, the 1999 House of Representatives considered House Resolution 176, which expressed its approval for Brown. 145 CONG. REC. H3272 (daily ed. May 18, 1999) (statement of Rep. Thompson) (introducing the resolution); $i d$. at $\mathrm{H} 3273$ (agreeing to the resolution by unanimous consent thereby resolving that the House of Representatives recognizes the "historical significance" of Brown and recognizes its significance as a watershed in advancing the "basic American principles of freedom, Justice, and equality under the law").

30. Richard Kluger, SimPle JUSTICE 605-09 (1975) (discussing the memorandum, reaction to it, and the likelihood that it was authored by William Rehnquist).

31. 136 Cong. ReC. 25,293 (1990) (statement of Sen. Cranston). Others, such as Senator Weicker, emphasized that the Bork hearings revealed popular support for protection of minorities and the need for Congress to be more involved in such constitutional issues. 134 ConG. REC. 4262 (1988) (statement of Sen. Weicker). He observed:

Do you remember how this whole Nation became incensed just a few months ago during the nomination vote of Justice Bork, blaming Justice Bork for his deficiencies on civil rights and human rights issues? But there was one statement that Bork made that was absolutely correct, which is that the primary responsibility sits in the hands of the legislative and executive branches of government not the courts. The courts are the last refuge, the last defense for the rights of all Americans. They are not the first. But we have put the courts in that position by refusing to deal with the issues of this Nation ourselves. 
The Bork/Brown events reveal that a confirmation hearing can provide a vehicle for the Senate to ratify a constitutional decision made by the Supreme Court. A similar point might be possible for Roe v. Wade as well. Indeed, Justice Souter's confirmation hearing could be seen as laying the groundwork for the 1992 Casey $^{32}$ decision by helping to demonstrate that social attitudes have crystallized around a legal right to abortion and that restricting abortion now risks upsetting women's status in society. ${ }^{33}$

This account of the advice and consent process differs from the one made by political scientists and law professors. The conventional account assumes that a nominee will be influenced by his or her confirmation hearing and therefore vote in a certain way. ${ }^{34} \mathrm{I}$ am arguing that the other eight Justices on the Court also should be influenced by the Senate's constitutional judgments during nomination hearings. Through this interplay between Court and Congress, the Court can prompt legislative consideration of constitutional issues when inertia in Congress prevents particular issues from coming to the fore. ${ }^{35}$ This

Id.

32. Planned Parenthood v. Casey, 505 U.S. 833 (1992).

33. E.g., 138 CONG. REC. 16,487 (1990) (statement of Sen. Wirth) (supporting the Freedom of Choice Act "to reestablish what has been a fundamental right ... and . . . is now . . . under significant attack"); 136 CONG. REC. 26,981 (1990) (statement of Sen. Packwood) ("I am convinced that Judge Souter is cognizant of the legal chaos that would ensue if the right to choose is struck down. ... I take [his statements] as encouraging signs that [t]his nominee would recognize that the right to choose is fundamental."); 136 CONG. REC. 26,974 (1990) (statement of Sen. Wirth) (noting that "Souter did not address the fundamental right to privacy with as much clarity as [the Senator] would have liked" but expressing the hope that Souter will continue "to support the fundamental individual rights"); 136 CONG. REC. 26,972 (1990) (statement of Sen. Kohl) (describing reproductive choice as a "fundamental right" and expressing concern over Souter's failure to address the issue); 136 CONG. REC. 25,293 (1990) (statement of Sen. Cranston) (same); see also 135 CONG. REC. 7485 (1989) (statement of Rep. Morella) ("There is no precedent in the two hundred years of this Court's history for overruling a decision recognizing a fundamental right. Roe versus Wade recognized a fundamental right solidly based in constitutional principles and precedent.").

34. The Senate is unlikely to confirm a nominee whose views about a constitutional decision run contrary to that of a clear majority. MARTIN SHAPIRO, FreEdom OF SPEECH: THE SUPREME COURT AND JUDICIAL REVIEW 27 (1966) (noting the improbability that "the Court could long hold out against entrenched majority sentiment"); Robert A. Dahl, Decision-Making in a Democracy: The Supreme Court as a National Policy-Maker, 6 J. PUB. L. 279, 284-85 (1957):

A president can expect to appoint about two new Justices during one term of office; and if this were not enough to tip the balance on a normally divided Court, he is almost certain to succeed in two terms. ... The fact is, then, that the policy views dominant on the Court are never for long out of line with the policy views dominant among the lawmaking majorities of the United States.

35. There may be practical problems, such as the difficulty in determining what the 100 members of the Senate believed about a particular issue. Confirmation hearings could be formally structured to provide for votes on constitutional issues, or informal settlement of these matters may take place once the Senate is invested with the greater interpretive power I am ad- 
exchange between branches means that a constitutional decisionmaker need not anticipate every possible outcome before making a judgment, since the decisions are subject to adjustment and possible reversal not just by one entity, but by two. ${ }^{36}$ Ex post resolution has other advantages, such as permitting empirical data to be gathered and additional commentary to flow in about the merits of a particular decision. It also casts the Court as an agent of subtle constitutional change, an agent that crystallizes and refines particular constitutional issues so the nation is aware of them and can make informed decisions. ${ }^{37}$ We now turn to one of the chief advantages of this proposal, which is that it provides a promising solution to the abstraction question.

\section{B. Abstraction}

A persistent problem in constitutional interpretation concerns the role of abstraction. The vague language of the Constitution, such as its Due Process Clause, must be applied to contemporary circumstances. Bruce Ackerman has put forth an important defense of judicial abstraction in his attempt to dissolve the countermajoritarian difficulty. Analyzing his defense reveals some problems with his theory of interpretation and demonstrates an advantage of using the Senate's advice and consent power to perform the role of abstraction.

In recent work, Ackerman has attempted to describe and defend the use of critical legislative and executive determinations as constitutional guideposts for judicial interpretation. ${ }^{38}$ Ackerman distinguishes between two types of decisions, those made by the people and those

vocating. Despite such difficulties, on balance the approach would yield more representativeness than one based on judicial supremacy.

36. The infusion of popular values into the Constitution is best accomplished when Congress is open and honest about close constitutional questions. Often when text, history, structure, and precedent do not provide clear answers, the Supreme Court nevertheless attempts to paint a clear picture of these sources. This is what Learned Hand referred to as "sweeping all the chessmen off the table." LEARNED HAND, THE SPIRIT OF LIBERTY 131 (3d ed. 1960). That approach might be necessary to preserve the myth of judgment and increase the legitimacy of the Court, but it has no place in Congress, whose legitimacy is derived from being elected by the people. Congress, therefore, should admit close constitutional questions in confirmation hearings and fully explain their reasons for decision, even when those reasons rest on popular values.

37. Cf. Gerald Rosenberg, The Hollow Hope 336-43 (1991) (contending that the Court generally has little role in promoting social change in the face of serious barriers). The proposal I am suggesting, by contrast, contends that the Court has a modest and subtle role in framing and crystallizing constitutional issues, and by placing certain constitutional items on the national agenda.

38. 1 Bruce Ackerman, We the People: Foundations 6 (1991). 
made by the government. ${ }^{39}$ Decisions made by the people involve a complicated deliberative process whereby a large number of citizens become convinced of the need to change the law. Decisions made by government occur all the time and are subject to the higher law constraint of the few prior decisions made directly by the people. ${ }^{40}$

Unfortunately, the people rarely speak. Ackerman tells us that they have spoken fully in only three "constitutional moments"-the Founding, Reconstruction, and the New Deal. ${ }^{41}$ The paucity of concrete principles from higher lawmaking requires someone to interpret these principles in specific circumstances. It is here that Ackerman's argument runs into trouble. Because the three moments will not by themselves answer the majority of tough questions in constitutional law, Ackerman believes that judges should "synthesize" the values from each moment to find answers to contemporary problems. ${ }^{42}$ Judges are supposed to read the principles of the Founding through the lens of Reconstruction and the New Deal. ${ }^{43}$ By abstracting the values of these time periods to contemporary problems, Ackerman argues, judges will be able to decide cases in a way that dissolves the countermajoritarian difficulty. ${ }^{44}$

I believe that Ackerman's synthetic solution creates major problems of indeterminacy and runs the risk of reinforcing the Court's countermajoritarianism. In the course of explaining this, I shall use his case examples to underscore some of the benefits of legislative abstraction. Ackerman illustrates his interpretive theory with two examples in Volume I of We the People. ${ }^{45}$ The first example is Brown v. Board of Education, ${ }^{46}$ a case to which I shall later return. His second example is Griswold v. Connecticut, where the Court struck down a Connecticut prohibition on contraceptives on the ground that it violated the right to privacy. ${ }^{47}$ The Court's opinion found this right to privacy in the "penumbra" of various constitutional amendments. ${ }^{48} \mathrm{~A}$ problem immediately arises: the Constitution does not contain a right

\footnotetext{
39. 1 id. at 6

40. 1 id. at 6; Bruce A. Ackerman, The Storrs Lectures: Discovering the Constitution, 93 YALE L.J. 1013, 1046-56 (1984).

41. 1 ACKERMAN, supra note 38 , at 58-67.

42. 1 id. at $132-33,159-62$.

43. 1 id. at 262

44. 1 id. at 262 .

45. $1 \mathrm{id}$. at $131-59$.

46. 347 U.S. 483 (1954).

47. 381 U.S. 479,485 (1965).

48. Id. at $484-85$.
} 
to privacy. To some, therefore, Griswold reeks of the countermajoritarian difficulty. ${ }^{49}$ Ackerman disagrees with these contentions, arguing that Griswold is an exercise in judicial borrowing of "freedom of contract" ideals in a post-New Deal world. ${ }^{50}$ In other words:

1) The Constitution's Founders used language that does not protect privacy, but does protect the freedom of contract.

2) Freedom of contract is emblematic of the type of liberty that prevents government from undermining economic freedom.

3) The New Deal has repudiated this idea of freedom of contract, and has legitimated economic intervention.

4) The privacy right to contraceptives is analogous to the right to contract, insofar as both protect an individual from unwanted interference by the government.

5) To preserve the Founding ideas of liberty in light of the New Deal, the Court recognizes a right to privacy in the sexual arena.

49. E.g., BORK, supra note 7, at 95-100 (arguing that the "right of privacy" created in Griswold is "nothing more than a warrant judges ... created for themselves to do whatever they wished").

50. 1 ACKERMAN, supra note 38 , at 159 :

Griswold's reinterpretation of the Founding texts in terms of a right to privacy, rather than a right to property and contract, is nothing less than a brilliant interpretive proposal. Granted, when the Founders thought about personal freedom they used the language of property and contract; given the New Deal repudiation of this language, doesn't the language of privacy provide $u s$ with the most meaningful way of preserving these Founding affirmations of liberty in an activist welfare state?

Consider Ackerman's remarks in a separate article as well:

The core of both "privacy" and "property" involves the same abstract right: the right to exclude unwanted interference by third parties. The only real difference between the two concepts is the kind of relationship that is protected from interference"property" principally protects market relationships while "privacy" protects more spiritual ones. Yet surely this fact should not prevent recognition of "privacy" as a dimension of constitutional "property in its widest sense."

Bruce Ackerman, Liberating Abstraction, 59 U. CHI. L. REV. 317, 347 (1992). Similar ideas are at play in Ackerman's reading of other cases, such as Bowers v. Hardwick, 478 U.S. 186 (1986): "[A]ny reasonably competent lawyer can see that the same basic legal ideas are at play in Lochner and Bowers: property, conceived as the right to exclude others, and contract, conceived as the right to arrange mutually advantageous terms for association." Ackerman, supra, at 343.

51. 1 ACKERMAN, supra note 38, at 153-57 ("[A]t the heart of Griswold is the act of synthetic interpretation-an effort to integrate Founding text with New Deal transformation to make sense of both parts of our evolving heritage."). 
Ackerman thus believes that although neither of the two relevant constitutional moments (the Founding and the New Deal) dealt with personal privacy, such an intent can be divined from the abstract views of the Founders in light of the New Deal.

This conclusion is far from obvious. Let us start with the text of Griswold, which never mentions the right to contract (though it mentions numerous other constitutional provisions in support of its penumbra approach). ${ }^{52}$ The quality of the analogy between contract and privacy appears strained-each is grounded in personal liberty, yet each claims a completely different sphere of liberty (economic or social, respectively). Given the differences between privacy and contract, it is no surprise that the Supreme Court has not explained the right to privacy in terms of contract in any of its subsequent privacy opinions. Thus, Ackerman leaves us with a curious, and possibly overly creative, approach to reading opinions.

Creativity is not the only flaw with this approach. The fundamental problem is that it operates on a very high level of abstraction, and it is therefore plagued with indeterminacy. After all, just how was the Court supposed to derive the modern-day privacy principle from contract and property rights in the ancien regime? Suppose, for example, that the Griswold Court in 1965 had decided to engage in a different sort of synthesis between Founding and New Deal values:

A) The New Deal authorized government interference in the economy.

B) In an attempt to see what remains of our Founding values in the wake of the New Deal, the Court will look back and synthesize.

C) Looking back, we see that the abstract values of the Founders originated from the transcendental enlightenment ideal that social and economic rights are part of the same whole.

D) Therefore, to preserve the equivalence of social and economic rights at the Founding, this Court finds that government intervention in the social sphere-such as prohibitions on contraception-has been legitimated by the New Deal's interventionist logic.

52. Griswold v. Connecticut, 381 U.S. 479, 464 (1965) (describing the First, Third, Fourth, Fifth, and Ninth Amendments as supportive of the right to privacy). 
Indeed, the two dissenters in Griswold-Justices Black and Stewartcame to their results by following a somewhat similar interpretive path. As Ackerman concedes, these two engaged in synthesis of the constitutional moments of the Founding and New Deal and came to a conclusion opposite to that of the majority. ${ }^{53}$ What standards and rules would Ackerman use to explain why the reasoning above is wrong and why Douglas was right?

Much is at stake here. If Ackerman's theory-by relying on abstraction-yields an indeterminate result, then the Court in cases such as Griswold may be synthesizing in a manner inconsistent with higher lawmaking at crucial moments in time. The result is not the dissolution of the countermajoritarian difficulty, as Ackerman promises. Instead the upshot of Ackerman's proposal is a theory of interpretation that flouts the people's true wishes. It is of course possible that this will not happen, and that courts will maintain fidelity to higher law through synthesis at an appropriate level of abstraction. Nevertheless, once the indeterminacy problem is recognized, it is difficult to reason from democratic principles that an unelected judiciary should have the power to use synthesis to trump the views of the people simply because of the possibility that it might actually get things right. (Even a broken clock is right twice a day.) Indeterminacy means that a court can reach the opposite result from the one intended by the people, because there are two or more plausible outcomes. ${ }^{54}$ Such malleability is especially problematic when trying to understand the values of a large group of people who died long ago. Indeed, at one point, Ackerman criticizes Gordon Wood for the Beardian influence in his discussion of the Founding. ${ }^{55}$ If Gordon Wood, who has dedicated years to trying to understand the Founders' views as a professional historian, cannot know the Founders' abstract values, how can we put more faith in generalist judges who are not trained as historians and who write scores of opinions each year?

Given the high probability of indeterminacy in hard constitutional cases where abstraction might provide an answer, I suggest that Congress is the institution best suited to engage in interpretive abstraction. Ackerman assumes that the judiciary is the institution that

53. 1 ACKERMAN, supra note 38 , at 157 .

54. There are, of course, many justifications for Griswold, such as the fact that the law was decades old and enacted before women had the right to vote, that it was out of step with contemporary views, and so on. But the one justification that Ackerman puts forth, that it was a permissible synthesis of New Deal and Founding values, creates indeterminacy.

55. 1 ACKERMAN, supra note 38, at 219-21. 
should use abstraction. ${ }^{56}$ But courts are not very good at performing this role. They reach different results depending on the level of generality they pick. ${ }^{57}$ There is little or no accountability for their choices. By contrast, if the Senate were to use its advice and consent power in periods of ordinary politics in a backward-looking manner, with reference to the ideals and values prevailing during Ackerman's three moments of strong constitutional significance, perhaps Ackerman's theory could be rehabilitated. The Senate's task would be limited to the same task that Ackerman proposes that courts undertake in periods of ordinary lawmaking, namely, the interpolation of abstraction.

Congress therefore should exert a larger role in bridging the gap between ordinary and higher lawmaking by inserting itself into interpretive questions and self-consciously trying to find consensus on the abstract values and lessons of different constitutional moments. This would minimize the countermajoritarian difficulty, because politically accountable actors would be bringing their perspectives about the Constitution to bear. ${ }^{58}$ As suggested above, a virtual consensus has formed during the past twelve years that Brown v. Board of Education reached the correct constitutional result-even if we are not completely sure of why that is so. Perhaps it is possible to derive Brown's legitimacy not just from the synthesis that the Court con-

56. $1 \mathrm{id}$. at 86-94; Ackerman, supra note 50, at 333-34 (suggesting that "the judicial patterns of response to particular abstractions provide an index of the power of each past generation to make its constitutional ideals an enduring part of modern law"). I am particularly dubious about this prospect with respect to time-pressed, generalist, inexperienced, and insulated lower courts and the obvious accountability issues. Understandably, an ordinary Congress does not have as much legitimacy to speak for the people as does a Congress at a moment of higher lawmaking. But this point applies with equal, if not greater, force to the unaccountable and barely visible courts in most periods of ordinary politics.

Ackerman has, at one point, recognized that the President and Congress might create a constitutional moment through "transformative appointments" to the Supreme Court. Bruce A. Ackerman, Transformative Appointments, 101 HARV. L. REV. 1164, 1170-71 (1988). But his suggestion is a far cry from what I am proposing, which is a mechanism to update the Constitution by asking Congress to resolve abstraction issues through simple and ordinary legislative interpretation of the Constitution. No grand new philosophy that encompasses every pressing legal issue, no major moment, is necessary to accomplish this task. All that should occur is that Congress take its role seriously as a body that attempts to discern the abstract lessons of history during Supreme Court confirmation hearings.

57. As Dean Brest has written in a different context, "The indeterminancy and manipulability of levels of generality is closely related, if not ultimately identical, to the arbitrariness inherent in accommodating fundamental rights with competing government interests." Paul Brest, The Fundamental Rights Controversy: The Essential Contradictions of Normative Constitutional Scholarship, 90 YALE L.J. 1063, 1085 (1981).

58. For one possible suggestion of this, see Poe v. Ullman, 367 U.S. 497, 542 (1961) (Harlan, J., dissenting) (emphasizing that courts must interpret "due process" in accordance with "the balance struck by this country" rather than the "unguided speculation" of judges). 
ducted in 1954 (to the extent that the Court conducted a synthesis), but also from the synthesis of Founding values enshrined in the Declaration of Independence with more modern principles of equality-a synthesis that Congress recognized post hoc in the Bork nomination. Griswold, then, might be justified not because of a synthesis by the Warren Court, but rather because it was a judicial proposal that Congress later blessed in confirmation hearings.

It is possible to envision other situations where Congress imparts authority and legitimacy to a constitutional decision ex post through this mechanism of legislative ratification. Even if the Court's constitutional pronouncement in a given case is not faithful to the history and intent of the Constitution, that decision might nevertheless be legitimate because Congress has ratified it. In one respect, this is the twobranch analogue to stare decisis in the judicial system. Stare decisis holds that a decision, even if not legitimate at the time, can become legitimate once social expectations have crystallized around it. Here, it is Congress, not a court, that confers legitimacy on a prior holding. (Ex post legitimacy is not unusual in law. For example, the doctrine of adverse possession and, more generally, the lawfulness of the product of the 1787 Philadelphia Convention-which brushed aside the presumably still-binding Articles of Confederation-illustrate the law's tendency to legitimate even dubious prior claims. ${ }^{59}$ ) There is a more obvious point to be made about stare decisis, which is that Congress, and not the Court, might be in a better position to decide whether social expectations have indeed crystallized around a given constitutional interpretation. ${ }^{60}$ The signals that reveal such crystallization are best read by Congress, not the Court.

Social transformations seldom occur in one grand Ackermanian moment. They are instead the product of subtle changes in mores over long periods of time. The changing notions of equality in the second half of the twentieth century are one such example; the revolution in sexual attitudes due to the advent of the birth control pill is another. These changes often occur below the radar screens of an insulated Supreme Court, but they are precisely the kinds of things that Congress understands. Legislative constitutional interpretation can give effect to these subtle shifts and adjust constitutional doctrine accordingly. For example, such interpretation provides a powerful ex-

59. Bruce Ackerman \& Neal Katyal, Our Unconventional Founding, 62 U. CHI. L. REV. 475, 569 (1995).

60. Planned Parenthood v. Casey, 505 U.S. 833, 865-67 (1992). 
planation for the legitimacy of Griswold, which may be grounded not in the contortionist's trick of New Deal synthesis, but in the change in attitudes toward sexuality that had little to do with the government and a lot to do with science. Congress stands in a better position to assess these changes than the Court. If nothing else, Congress remains accountable for its assessments in ways the Court is not.

To sum up, the Senate should use the advice and consent process to translate abstract constitutional concepts. Surrendering this task to the judiciary risks indeterminacy and unaccountability. ${ }^{61}$ Wielding the Senate's power in this fashion gives the people a voice in constitutional interpretation. Moreover, by liberating Congress from overly rigid views of text, history, and precedent, constitutional accountability is enhanced. Under my proposal, senators will not be able to plead, "The Court made me do it," when confronted with tough constitutional questions. Instead, they will have to explain why they believe a particular interpretation is correct. ${ }^{62}$ Hearings should examine and decide the key constitutional questions of the day and should not be simple regurgitations of existing case law.

Several objections to using advice and consent in this way present themselves. Some might argue that the Senate is not competent to conduct such abstractions. Empirical evidence suggests the contrary, however (at least vis-à-vis the judiciary), and the Senate has the advantage of being politically accountable for its mistaken judgments. ${ }^{63}$ Others might argue that the Constitution can change only by formal

61. A certain degree of congressional interpretation of the Constitution is inevitable under any interpretive system, as the Court has the ability (which it uses all the time) to employ the passive virtues at any time it wishes; such techniques can be used to decline to hear certain issues from war powers to affirmative action. BICKEL, supra note 13, at 126-27; Charles Tiefer, The Flag-Burning Controversy of 1989-1990: Congress' Valid Role in Constitutional Dialogue, 29 HARV. J. ON LEGIS. 357, 382-84 (1992).

62. This unique feature of congressional interpretation justifies, for example, Representative St. George Tucker's 1818 declaration on the floor of Congress that "in the construction of this Constitution, there is not, there cannot be, a system of orthodoxy." 32 ANNALS OF CONG. 1323 (1818).

63. Walter F. Murphy, Who Shall Interpret? The Quest for the Ultimate Constitutional Interpreter, 48 REV. POL. 401, 408 (1986) (stating that Congress's consideration of some constitutional questions "stand[s] up well against the Justices' most sophisticated analyses" and that "the Justices are themselves adept at evading constitutional issues, the level of argument among them is not always high, and they are not invariably sensitive to constitutional problems"); Tiefer, supra note 61, at 382-84. But see Paul Brest, Congress as a Constitutional Decisionmaker and Its Power to Counter Judicial Doctrine, 21 GA. L. REV. 57, 98 (1986) (criticizing such views); Abner J. Mikva, How Well Does Congress Support and Defend the Constitution?, 61 N.C. L. REV. 587, 610 (1983) (proposing that "Congress has not been a model of constitutional decisionmaking" and that "its hallmark has been superficial and, for the most part, self-serving constitutional debate"). 
amendment, ignoring the fact that this does not describe our Constitutional tradition, nor should it. ${ }^{64}$ Still others would argue that the politicization of Congress clouds proper constitutional judgment. ${ }^{65}$ If the Senate took a more aggressive role in constitutional interpretation, however, the President might have less incentive to pack the courts with stealth partisans, and the Justices might feel less pressure to revisit political battles that have been lost by their compatriots in Congress.

In other words, a problem with criticizing congressional interpretation is that the criticism uses the status quo as the baseline, and the Court is primarily responsible for interpreting the Constitution at present. If Congress assumed greater interpretive power, there are reasons to believe it would make better constitutional decisions. Congress's somewhat sullied track record may be caused, as Thayer suggested 100 years ago, by the Court's aggrandizement of constitutional power. ${ }^{66}$ More recently, my colleague Mark Tushnet described the negative influence of the "judicial overhang"- the tendency by the Court to eclipse Congress's constitutional decisions. ${ }^{67}$ Even if one thinks that the courts are more competent at answering these questions, the possibility for correction and transparency may outweigh the incremental benefits that courts provide. On balance, constitutional interpretation by the Senate would be more transparent, and thus more easily corrected by pressure from the voting public.

The most powerful objection to such use of the advice and consent power is that the Senate might abuse it to serve majoritarian ends and undermine minority rights. To the extent that clauses in the Constitution are designed to protect minority rights, it may be sensible not to lodge the power of abstraction in the Senate during times

64. E.g., Akhil Reed Amar, The Fifty-Seventh Cleveland-Marshall Lecture: "The Bill of Rights and our Posterity," 42 CLEV. ST. L. REV. 573, 573-74 (1994) ("The very words of the Bill of Rights would themselves educate Americans-indeed, the Bill was written in clean, grand phrases that could be easily memorized and internalized (like scripture, or poetry) in classrooms across the Republic."); Kathleen M. Sullivan, Constitutional Amendmentitis, AM. ProsPect, Fall 1995, at 20, 22 (criticizing the large number of constitutional amendments considered by Congress).

65. Brest, supra note 63 , at 83 ("[W] usually expect legislators to be interested and partisan. If we are skeptical about the capacity of judges to set aside their own social or political views when interpreting the Constitution, many would view the claim that legislators have this capacity with utter incredulity.").

66. James B. Thayer, The Origin and Scope of the American Doctrine of Constitutional Law, 7 HARV. L. REV. 129, 156 (1893). (1999).

67. Mark Tushnet, Taking the Constitution Away from the Courts 57-65 
of ordinary lawmaking. For this reason, I suggested at the outset that the Court should give a presumption of validity only to those Senate decisions that increase individual rights. After all, the Senate might be in a better position to protect individual rights, because the Court may dilute protections out of fear that strong pronouncements will create a flood of cases from people convicted under a previous interpretation of a law or doctrine. ${ }^{68}$ Or the Court may reduce constitutional guarantees because it fears trying to manage a judicially imposed remedy. ${ }^{69}$ Congressional guidance may help alleviate these problems. Finally, it is by no means clear that the Court is free from acting in ways that undermine individual rights. Life tenure may promote courage, but courage can be put to all sorts of nefarious ends. As we shall see, the question is how much independence we are willing to lose in favor of accountability.

Moreover, the current degree of legislative influence over judicial decisionmaking should not be underestimated. After all, there is a well-established practice of judicial deference to Congress-deference that is rooted, at bottom, in the faith of Congress to make adequate constitutional judgments. "Congress, like th[e] Court, is bound by and swears an oath to uphold the Constitution. The courts will therefore not lightly assume that Congress intended to infringe constitutionally protected liberties or usurp power constitutionally forbidden it." ${ }^{70}$ Such deference has a pedigree that dates as far back as

\section{Cooley says:}

It will of course sometimes happen that a court will find a former decision so unfounded in law, so unreasonable in its deductions, or so mischievous in its consequences, as to feel compelled to disregard it. Before doing so, however, it will be well to consider whether the point involved is such as to have become a rule of property, so that titles have been acquired in reliance upon it, and vested rights will be disturbed by any change; for in such a case it may be better that the correction of the error be left to the legislature, which can control its action so as to make it prospective only, and thus prevent unjust consequences.

Thomas M. Cooley, A Treatise on the Constitutional Limitations Which Rest UPON THE LEGISLATIVE POWER OF THE STATES OF THE AMERICAN UNION 52 (1st ed. 1868). The Court and Congress have worked out schemes whereby the Court has the ability to grant only prospective relief in certain cases, but there are restrictions on this jurisprudence even after Congress's blessing of this with the 1996 Anti-Terrorism and Effective Death Penalty Act. See 28 U.S.C. § 2254(e) (1994); see also Paul J. Mishkin, The Supreme Court, 1964 Term-Foreword: The High Court, the Great Writ, and the Due Process of Time and Law, 79 HARV. L. REV. 56, 60-62 (1965).

69. Lawrence Gene Sager, Fair Measure: The Legal Status of Underenforced Constitutional Norms, 91 HARV. L. REV. 1212, 1213-15 (1978).

70. DeBartolo Corp. v. Fla. Gulf Coast Bldg. \& Constr. Trades Council, 485 U.S. 568, 575 (1988). In other circumstances, the Court has stated that "[ $t]$ he customary deference accorded the judgments of Congress is certainly appropriate when, as here, Congress specifically considered the question of the Act's constitutionality." Rostker v. Goldberg, 453 U.S. 57, 64 (1981). 
Stuart v. Laird ${ }^{71}$ and is reflected in early and important writings on the Constitution, such as Cooley's ${ }^{72}$ and Thayer's. ${ }^{73}$ Indeed, Chief Justice Marshall made the same point in McCulloch $v$. Maryland ${ }^{74}$ and Justice Story made his famous decision in Martin v. Hunter's Lessee ${ }^{75}$ by relying "upon a foundation of authority" consisting not only of "judicial decisions of the Supreme Court through so long a period," but also of the "contemporaneous exposition" of the First Congress in the Judiciary Act. $^{76}$ Thus, we have judicial doctrines such as Thayer's clear-error rule that counsel deference to Congress in constitutional matters, as well as doctrines that suggest that statutes should be read to make them constitutional.

Some incrementalists may fear that my proposed use of the advice and consent power would conflict with City of Boerne v. Flores. ${ }^{77}$ In Boerne, Congress considered the constitutionality of the Religious Freedom Restoration Act, an Act that had as its stated purpose "[the]

The Court reaffirmed its commitment to giving deference to congressional interpretations of the Constitution in Stafford v. Wallace, 258 U.S. 495, 521 (1923) ("This court will certainly not substitute its judgment for that of Congress in such a matter unless the relation of the subject to interstate commerce and its effect upon it are clearly non-existent."), and United States v. Nixon, 418 U.S. 683, 703 (1974) ("In the performance of assigned constitutional duties each branch of the Government must initially interpret the Constitution, and the interpretation of its powers by any branch is due great respect from the others.").

71. 5 U.S. (1 Cranch) 299, 309 (1803) (dismissing a challenge to the constitutionality of the 1789 Judiciary Act and stating that "practice and acquiescence under [the Act] for a period of several years, commencing with the organization of the judicial system, affords an irresistible answer, and has indeed fixed the construction. It is a contemporary interpretation of the most forcible nature"). Deference to Congress is emphasized in other early cases. E.g., Sinking-Fund Cases, 99 U.S. 700, 718 (1878) ("Every possible presumption is in favor of the validity of a statute, and this continues until the contrary is shown beyond a rational doubt ... [and t] he safety of our institutions depends in no small degree on a strict observance of this salutary rule."); Ogden v. Saunders, 25 U.S. (12 Wheat.) 213, 270 (1827) ("It is but a decent respect due to the wisdom, the integrity, and the patriotism of the legislative body, by which any law is passed, to presume in favour of its validity, until its violation of the constitution is proved beyond all reasonable doubt.").

72. Cooley believed that a congressman may vote against a measure as unconstitutional, and then find himself placed on the bench later, where he may find it his duty to find the measure constitutional. COOLEY, supra note 68, at 53-54.

73. Thayer, supra note 66, at 144 (stating that courts should "not merely [apply] their own judgment as to constitutionality, but their conclusion as to what judgment is permissible to another department which the constitution has charged with the duty of making it"); see also Archibald Cox, The Role of Congress in Constitutional Determinations, 40 U. CIN. L. REV. 199, 200 (1971) (explaining that a "judge may feel obliged to accept a congressional determination that he as a Congressman would have rejected").

74. See supra note 8.

75. 14 U.S. (1 Wheat.) 304 (1816).

76. Id. at 352 .

77. 521 U.S. 507 (1997). 
restor[ation of] the compelling interest test." designed to overrule Employment Division v. Smith, ${ }^{79}$ which Congress felt had "virtually eliminated the requirement that the government justify burdens on religious exercise imposed by laws neutral toward religion." ${ }^{80}$ Congress invoked Section 5 of the Fourteenth Amendment to justify the legislation.

The Court found RFRA to be unconstitutional because Section 5 does not grant Congress "a substantive, non-remedial power." gress cannot define its own powers, the Court reasoned, nor can it alter the meaning of the Constitution at will. ${ }^{82}$ There are many points of agreement between the ideas advanced above and the Court's decision. Boerne began by observing that Congress has the power to deter constitutional violations even if its preventative steps interfere with conduct that is not itself unconstitutional. ${ }^{83}$ The majority then recognized that Congress should conduct much of the constitutional interpretation that takes place in the federal government:

When Congress acts within its sphere of power and responsibilities, it has not just the right but the duty to make its own informed judgment on the meaning and force of the Constitution. This has been clear from the early days of the Republic. In 1789, when a Member of the House of Representatives objected to a debate on the constitutionality of legislation based on the theory that "it would be officious" to consider the constitutionality of a measure that did not affect the House, James Madison explained that "it is incontrovertibly of as much importance to this branch of the Government as to any other, that the constitution should be preserved entire. It is our duty." Were it otherwise, we would not afford Congress the presumption of validity its enactments now enjoy. ${ }^{84}$

The Boerne Court then went on to emphasize that the case was not about what type of interpretation Congress should use. Instead, it was about the question of which branch should win in the event of a direct conflict between Congress and the Court:

78. Id. at 515 (citing 42 U.S.C. $§ 2000 b b(b) ~(1994))$.

79. 494 U.S. 872 (1990).

80. 42 U.S.C. $§ 2000 b b(a)$ (1994); see also Remarks on Signing the Religious Freedom Restoration Act of 1993, 2 Pub. PAPERs Of THE Presidents of the United STATEs 2000 (Nov. 16, 1993) ("[T]his act reverses the Supreme Court's decision Employment Division against Smith ....").

81. Boerne, 521 U.S. at 527.

82. Id. at $528-29$.

83. Id. at 517 .

84. Id. at 535 (citation omitted). 
It is for Congress in the first instance to "determin[e] whether and what legislation is needed to secure the guarantees of the Fourteenth Amendment," and its conclusions are entitled to much deference. Congress' discretion is not unlimited, however, and the courts retain the power, as they have since Marbury v. Madison, to determine if Congress has exceeded its authority under the Constitution. ${ }^{85}$

Boerne's belief in the Court's supremacy does not call into question much of what I am saying here. I have not argued that the Senate has the power to compel the Court to recognize its interpretation at any time and place. Rather, I have suggested that Congress can influence the path of judicial interpretation by more nuanced mechanisms than the Section 5 power. Nomination hearings for Supreme Court Justices are one such possibility. For the Senate to succeed in influencing the path of judicial decisionmaking, it must convince the Justices on the merits. The Senate's arguments must be so persuasive that they retain force even after the Senate has lost the bulk of its formal power to enforce its will. In the next part, we shall take up the question of whether Congress may use ordinary laws to overrule the Supreme Court. Even if Congress does not have that vehicle open to it, there are other ways for Congress to influence the path of the Court's decisionmaking in ways that harness each branch's comparative strengths.

The idea I have been describing in this section, that the Senate could update the Constitution through abstraction, has force even for those who do not subscribe to Ackerman's theory of multiple constitutional moments. Even if the only moment to be interpreted is the Founding (or two moments, the Founding and Reconstruction), the level of generality problem arises. ${ }^{86}$ Enabling the Senate to decide the level of abstraction by making the decisions about popular values may help the Constitution maintain contemporary relevance and majori-

85. Id. at 536 (citation omitted).

86. Consider some of the least persuasive pages in Bork's Tempting of America. In responding to Brest's claim that originalism required an arbitrary choice among levels of abstraction to determine whether the Equal Protection Clause protected Alan Bakke, Bork states that a judge must not make such arbitrary choices. Instead she or he must discover the meaning of the Clause. He then expounds on this theme for two pages, never once detailing what the meaning of the Clause was understood to be at the time, or why judges would be competent to figure it out. BORK, supra note 7, at 148-51. We are left with an ironic twist-those government actors who are the most problematic under Bork's theory of democracy are the ones who are given the power to determine what the Framers believed was the correct level of abstraction. 
tarian blessing. Such interpretation relies on what James Bradley Thayer called "the statesman's breadth of view." 87

Legislative synthesis may therefore be a better way to give life to our supreme constitutional values.

\section{LEGISLATION AND INTERPRETATION}

The robust view of advice and consent suggested in the preceding part raises the broader question of whether Congress can overrule the Court through its ordinary lawmaking power. In recent years, proposals along these lines have proliferated in the law reviews. In this part, I distinguish several different proposals and evaluate them from the perspective of accountability, individual rights, and constitutional structure. My view is that Congress can, in limited circumstances, use its legislative power to overrule the Court. The paradigm case for this occurs when Congress believes that the Court has improperly amended the Constitution in a way that reduces individual rights. Legislative constitutional interpretation that calls into question judicial decisions also can be appropriate in other limited circumstances.

\section{A. Types of Constitutional Supremacy}

Let me begin by identifying several different positions that can be taken with regard to judicial supremacy. Some will be familiar to readers, others are new.

Option 1: Pure Judicial Supremacy. The Court has the final say on constitutional questions. The views of Congress are entitled to no weight.

Option 2: Legislative Second-Look. The Court has the final say over a constitutional matter, but it may ask Congress for its views, just as it may ask the Solicitor General for the President's views.

Option 3: Judicial Advicegiving. The Court may write an opinion that is not technically binding but that puts Congress on notice about its constitutional views. That opinion may become binding in a later case.

Option 4: Judicial Second-Look. The Court strikes down a statute, but Congress can re-pass the same statute in order to signal its

87. Thayer, supra note 66, at 138. 
disapproval of the Court decision. The Court would still have the power to decide whether or not the statute is constitutional, and its decision would bind Congress. ${ }^{88}$

Option 5: Judicial Definition/Legislative Implementation. The Court has the responsibility to interpret the Constitution, but the question of what remedies are appropriate to rectify a constitutional violation is left to the legislature. The Court retains jurisdiction to review the remedy if it does not satisfy constitutional concerns.

Option 6: Judicial Deference to Legislative Pronouncements. The Court may retain supremacy over the Constitution but hesitate before striking down a statute out of respect for a coordinate branch of government or out of deference to particular factfinding made by the Congress.

Option 7: Declaratory, not Injunctive, Relief. The Court issues an opinion that explains why a course of conduct is unconstitutional in its view, but Congress is free to disregard the decision without risking contempt of court. Congress could therefore keep the law on the books, and the President may enforce it. ${ }^{89}$

Option 8: Congress Trumps the Court. A congressional decision is controlling, even if it flies in the face of an explicit Supreme Court opinion. Courts must then adhere to the congressional judgment.

Option 9: Populist Constitutional Law. The people can bypass government institutions and interpret the document, or at least portions of the document. Their interpretations would trump those of the Court or Congress. ${ }^{90}$

In trying to understand the advantages of each option, it is worth noting that some of these advantages can be captured through other constitutional mechanisms-such as advice and consent. Neverthe-

88. This corresponds somewhat to Guido Calabresi's "second-look" doctrine. See generally Guido CAlabresi, A COMMON LAW FOR THE AgE OF StATUTES (1982).

89. This proposal tracks, in some respects, the "departmentalist" position. See generally Frank H. Easterbrook, Presidential Review, 40 CASE W. RES. L. REV. 905 (1990); Gary Lawson \& Christopher D. Moore, The Executive Power of Constitutional Interpretation, 81 IowA L. REV. 1267 (1996).

90. See generally TUSHNET, supra note 67. 
less, crucial differences remain between congressional statutes and other legislative devices.

\section{B. Which Model of Supremacy Is Appropriate?}

As with any theory of constitutional interpretation, the advantages and disadvantages of each option will depend on the circumstances in a given case. One key determinant, however, will revolve around the tradeoff between accountability and independence. Let me illustrate this point by referring to two analogies, one from the Founding and one from the present day.

The zero-sum nature of the conflict between accountability and independence consumed our Founders' attention. In particular, several of The Federalist Papers (The Federalist Nos. 9, 10, 14, and 63) are devoted to explaining why the proposed Constitution struck the right balance between these values. The Federalist No. 9 and The Federalist No. 10 begin the discussion by explaining the difference between democracy and republican government. Madison, in The Federalist No. 10, claims that the first distinction lies in "the delegation of the Government." ${ }^{91}$ Publius believed that by delegating power, instead of leaving power with citizens through direct democracy, the system would "refine and enlarge the public views, by passing them through the medium of a chosen body of citizens, whose wisdom may best discern the true interest of their country, and whose patriotism and love of justice, will be least likely to sacrifice it to temporary or partial considerations." 92 The system would therefore "be more consonant to the public good, than if pronounced by the people themselves." ${ }^{\circ 3}$ The Federalist No. 10 was primarily concerned with trying to decide how much accountability, and how much independence, would be appropriate for our democratic republic. Its answer, that a compromise need be struck, and that horizontal and vertical diffusions of power were required to minimize the risk of infringements to liberty, is applicable to the question of judicial supremacy.

A modern-day analogy that illustrates this tradeoff is the Independent Counsel Act. ${ }^{94}$ Based on its twenty years of experience with the Act, Congress became convinced that the Act should lapse, in part because it gave too much independence to the Independent

\footnotetext{
91. The Federalist No. 10, at 62 (James Madison) (J.E. Cooke ed., 1961).

92. Id.

93. Id.

94. 28 U.S.C. $§ \S 591-599$ (1994).
} 
Counsel. The authors of the Act had believed that independence was necessary because of the risk that politics would hamper investigations; freeing prosecutors from political considerations was thought to produce the "right" prosecutions. Independence ultimately proved destructive, because it created a headless and uncontrollable monster not subject to the constraint of public opinion. ${ }^{95}$ Independence and accountability are mutually exclusive, and the Act sided with the former.

There is a strong parallel between the tradeoff in the Independent Counsel Act and congressional constitutional interpretation. As Americans, we have in large measure ceded our constitutional decisions to an independent body, the Supreme Court. We have come to believe that politics could corrupt constitutional choices and that an insulated body not concerned with reelection would produce the "right" decisions. There is a risk that, just as with the Independent Counsel Act, the same independence could undermine our constitutional system. Perhaps it is time to begin thinking about ways to structure a more accountable system of constitutional interpretation. This is of particular importance in the post-2000 era, where the Court took the unprecedented step of hand-picking its own successors by awarding the presidency to George W. Bush and thereby undermined a key structural check on a runaway Supreme Court-presidential elections. ${ }^{96}$

How we reconcile the conflict between accountability and independence will inform our decision about which type of supremacy is appropriate. Time and again, this irreconcilable conflict has led wellintentioned Americans to side with one view or the other in a variety of situations. This tortured history reveals that it is extremely difficult to determine how the balance between these two goals should be struck. Nevertheless, some lessons follow.

First, the importance of independence must be determined on a case-by-case basis. The reasons that undergird the need for judicial independence primarily stem from concerns espoused by those who believe the Constitution is designed to protect minorities. Without

95. See Reauthorization of the Independent Counsel Statute, Part I: Hearing Before the Subcomm. on Commercial and Admin. Law of the House Comm. on the Judiciary, 106th Cong. 3-4, 30-37 (2000) (statements of Chairman George W. Gekas and Deputy Attorney General Eric H. Holder, Jr.); The Future of the Independent Counsel Act: Hearing Before the Senate Comm. on Governmental Affairs, 106th Cong. 5-6, 247-83 (1999) (statements of Chairman Fred Thompson and Attorney General Janet Reno).

96. Neal Kumar Katyal, Politics Over Principle, WAsH. Post, Dec. 14, 2000, at A35. 
sufficient insulation from the ravages of majoritarian politics, the argument goes, a constitutional decision is likely to reflect the biases and wishes of the majority. Independence might be needed on an issue, say the Voting Rights Act, for the reasons stated by John Hart Ely. ${ }^{97}$ Less independence is needed on a matter such as the question of whether Congress can require sheriffs to conduct interim background checks on handgun purchasers. ${ }^{98}$ A one-size-fits-all approach to independence is not going to do the trick. Another strong argument for independence is based on legislative self-dealing. If a Constitutional interpretation is likely to benefit incumbents (for instance, interpreting the Constitution to forbid term limits or to preclude serious campaign finance reform), that decision should receive particular scrutiny by courts. ${ }^{99}$

Second, just as the need for independence varies with the context, so too does the need for accountability. Society needs a democratic mandate rather than a judicial one for some decisions. The issues that fit best into this category are those matters deemed "political questions." Impeachment, war powers, and the decision whether a constitutional amendment has been ratified are some examples. In each, the need for accountability trumps other goals.

I pause here to discuss an implication of these two points. The above discussion provides a new perspective on the tiers of scrutiny and their relationship to the political question doctrine, both of which have become standard doctrinal fare in the past century. The paradigm case for strict scrutiny occurs when there are process-based concerns. Nevertheless, there are circumstances in which process concerns exist but the courts remain silent. One way of thinking about such instances is that the need for accountability trumps process concerns.

\footnotetext{
97. John Hart Ely, Democracy AND Distrust 116-25 (1980).

98. See generally Printz v. United States, 521 U.S. 898 (1997) (holding that compelling states to administer a federal regulatory scheme in the context of background checks on handgun purchasers is unconstitutional); JESSE CHOPER, JUDICIAL REVIEW AND THE NATIONAL POLITICAL PROCESS (1980) (arguing, inter alia, that the Court should not decide constitutional questions respecting the power of the national government with regard to the states); Larry D. Kramer, Putting Politics Back into the Political Safeguards of Federalism, 100 CoLUM. L. REV. 215 (2000) (arguing that, contrary to the fears of the Founders, political parties have served to safeguard federalism); Herbert Wechsler, The Political Safeguards of Federalism: The Role of the States in the Composition and Selection of the National Government, 54 COLUM. L. REV. 543 (1954) (discussing the political participation of states as a political safeguard for federalism).

99. In addition, if Congress is using interpretation to expand its powers at the expense of the President, say by declaring a President's military activities abroad unconstitutional, heightened review would be appropriate as well.
} 
This observation suggests that a definition of strict scrutiny in the case law, which focuses on whether a minority is discrete and insular, reflects only part of the question. There may be circumstances in which a minority faces extreme prejudice, but the need for accountability -indeed, even a skewed accountability_trumps the need to protect minorities. This calculation is unspoken in tough cases like Korematsu v. United States, ${ }^{100}$ in which the Court confronted severe race-based restrictions but upheld them as valid. ${ }^{101}$ One can dispute how the Court weighs the accountability-versus-independence tradeoff, but that is the question between the lines in the case. In situations where the Court sides with accountability, its decisions may reflect concern about the prospect of judicial interference in the legislative process. Viewed from this perspective, the political question doctrine is simply the flip side of strict scrutiny and representationreinforcement theories.

Another major factor in choosing a supremacy model is specialized institutional competence. Again, determining which branch is most competent will differ from issue to issue. Although the Court might be particularly competent at understanding the nuances of the Confrontation Clause, it may be less able to understand the range of religious, social, and scientific views concerning death and dying. Some constitutional questions require a high degree of understanding about popular mores (impeachment may be a prime example). Such questions are better suited to legislative determinations than determination by the insulated Court.

Even in situations that appear ripe for judicial supremacy based on a need for independence or special competence, some legislative input may be necessary before a constitutional issue is put to rest. ${ }^{102}$ In such circumstances, using Option 2 or Option 3 (a legislative secondlook or judicial advicegiving), would provide a mechanism for the Court to obtain information without sacrificing judicial supremacy. If Congress cannot articulate a reasonable basis for its empirical judgments, then the Court may want to second-guess it, particularly if those judgments appear to have been influenced by motives that judicial supremacy was meant to defend against (such as legislative hos-

100. 323 U.S. 214 (1944)

101. Id. at 223-24.

102. One example is Judge Posner's opinion regarding affirmative action in boot camps. See Wittmer v. Peters, 87 F.3d 916 (7th Cir. 1996) (permitting data collection that would justify an affirmative action program to proceed despite constitutional concerns); Neal Kumar Katyal, Judges as Advicegivers, 50 STAN. L. REV. 1709, 1789-90 (1998) (discussing the Wittmer case). 
tility toward minorities). Both options permit repeated interactions between the branches over time.

Some, such as Larry Alexander and Fred Schauer, contend that any option that permits divided responsibility for constitutional decisions is bound to fail and that the judiciary must settle interpretive disputes. ${ }^{103}$ I disagree with this global proposition. ${ }^{104}$ Although stability is sometimes important in law, there are other goals that override stability-in particular, its focus on democratic participation, individual rights, and the like. ${ }^{105}$ Were stability our overriding concern, there would be no reason to prefer our Constitution to those of Burma or Iraq. By insisting on stability, we slight other values. For such reasons, instability is commonplace in American law. Many of our statutes are not stable over time-from our tax laws to our criminal prohibitions. When the courts strike down laws that are on the books, from RFRA $^{106}$ to the Gun-Free Schools Zone Act, ${ }^{107}$ this too undermines stability.

Congressional interpretation, by contrast, gives content to the notion that the people play a role in our constitutional government. Our Constitution does not presume to have all the answers. Rather, it is anticipated that constitutional struggles will emerge over time. Such struggles are healthy and part of the document's design. (Thomas Jefferson, in an extreme version of this argument, hoped that massive struggles in the form of revolutions would occur after the Founding to imbue our Constitution with popular ideals. ${ }^{108}$ ) Matters like Supreme Court confirmation hearings allow for legislative participation and in-

103. Larry Alexander \& Frederick Schauer, On Extrajudicial Constitutional Interpretation, 110 HARV. L. REV. 1359, 1362 (1997).

104. In part, the argument's unpersuasiveness stems from the fact that the authors dance around an exception to their rule: Dred Scott. Alexander and Schauer argue that President Lincoln may have been correct in his decision not to follow the Supreme Court's opinion, but that this does not undermine their claim because the wrong of Lincoln's disobedience "was outweighed by the greater wrong that would have occurred had the war been lost." Id. at 1382-83. Once this exception is admitted, however, there is no reason to expect constitutional certainty to exist. Presidents and members of Congress will always appeal to the exception-and the stability that the authors crave will be illusory.

105. But see COOLEY, supra note 68 , at 54 ("The general acceptance of judicial decisions as authoritative, by each and all, can alone prevent confusion, doubt, and uncertainty, and any other course is incompatible with a true government of law.").

106. City of Boerne v. Flores, 521 U.S. 507 (1997).

107. United States v. Lopez, 514 U.S. 549 (1995).

108. Letter from Thomas Jefferson to James Madison (Jan. 30, 1787), in THE PoRTABLE ThOMAs JeFFERson 415, 416-17 (Merrill D. Peterson ed., 1975). 
put, as we have seen, and explain why the stability Alexander and Schauer seek will be elusive. ${ }^{109}$

Indeed, in a system of divided government that separates powers, a monopoly over constitutionalism is something to be feared. As James Madison put it to the first Congress:

There is not one Government ... in the United States, in which provision is made for a particular authority to determine the limits of the constitutional division of power between the branches of the Government. In all systems, there are points which must be adjusted by the departments themselves, to which no one of them is competent. $^{110}$

Inherent in the concept of separation of powers, Madison claims, is the view that constitutional questions cannot always be settled by any one actor. Even if constitutional stability is important, it does not follow that the judiciary is the best institution to engender this stability. ${ }^{111}$ After all, one could say that Congress, not the courts (and certainly not the lower courts), should have the power to settle constitutional questions.

In response, the judicial supremacists cry "Marbury." Nothing in Marbury, though, requires the Court to have the final say over consti-

109. Underlying this view is a related point that even if the Constitution exists to provide stability, that stability may be procedural, rather than substantive. That is, the Constitution simply sets out the ways in which the Constitution's meaning may change, and that the form of stability is ultimately much more important than the meaning of, say, the Fourth Amendment. By channeling our revolutionary impulses into constitutional politics-either through high mechanisms such as constitutional amendments or lower ones like voting out members of Congress with whose constitutional interpretations we disagree-the Constitution regularizes the process of constitutional change. Alexander and Schauer claim that judicial supremacy follows from the notion that law "settles authoritatively what is to be done," Alexander \& Schauer, supra note 103 , at 1371, but our Constitution may simply set out the procedures, rather than the substance, of what is to be done. That is still law, and indeed may be more consistent with our Founding ideals. Ackerman \& Katyal, supra note 59, at 476-78.

110. 1 AnNALS OF CONG. 500-01 (Joseph Gales ed., 1789); see also Letter from Thomas Jefferson to William Jarvis (Sept. 28, 1820), in 15 WORKS OF THOMAS JEFFERSON 276-79 (criticizing Jarvis for viewing "judges as the ultimate arbiters of all constitutional questions" and saying that the "Constitution has erected no such single tribunal, knowing that to whatever hands confided, with the corruptions of time and party, its members would become despots. It has more wisely made all the departments co-equal and co-sovereign within themselves").

111. The Supreme Court's own willingness to overrule itself cuts against the validity of their point-witness the change from United States v. Darby, 312 U.S. 100 (1941), to National League of Cities v. Usery, 426 U.S. 794 (1976), to Garcia v. San Antonio Metropolitan Transit Authority, 469 U.S. 528 (1985), to New York v. United States, 505 U.S. 144 (1992)-just to take one example. Is this really an authoritative construction? This is particularly the case when lower courts start getting involved, for they often disagree with one another and the Supreme Court cannot resolve all of their disagreements. 
tutional issues. The decision merely confirms that the Court has $a$ say. ${ }^{112}$ Moreover, as Professor Monaghan's excellent description of "constitutional common law" reveals, many of the Court's constitutional pronouncements are already modifiable by Congress. ${ }^{113}$ Monaghan provides a number of examples, from the exclusionary rule to the First Amendment. He believes that the practice of constitutional common law is justified because it "opens a dialogue with Congress" and "provides the Court with a means for involving Congress in the continuing process of defining the content and consequences of individual liberties." 114

Judicial supremacists also point to The Federalist No. $78,{ }^{115}$ but that famous paper also emphasized the weakness of the judiciary. We have all heard Hamilton's famous invocation of the judiciary as "the least dangerous" branch, that courts have "neither Force nor Will, but merely judgment." 116 Most descriptions of these phrases emphasize the institutional limits of the judiciary. Hamilton also may have been referring to something else. In The Federalist No. 81, Hamilton answers the objection that the Constitution gives the Supreme Court too much power through judicial review. The charge is described by Hamilton:

112. See Marbury v. Madison, 5 U.S. (1 Cranch.) 137, 177 (1803) (referring to the "province and duty of the judicial department to say what the law is"). Marbury was read, only in the latter half of the twentieth century, to support the strong view of judicial supremacy. See Cooper v. Aaron, 358 U.S. 1, 18 (1958) (explaining that Marbury established the proposition "that the federal judiciary is supreme in the exposition of the law of the Constitution"); see also Planned Parenthood v. Casey, 505 U.S. 833, 868 (1992) (describing the Court as "invested with the authority to decide [the people's] constitutional cases and speak before all others for their constitutional ideals"); United States v. Nixon, 418 U.S. 683, 704 (1974) (speaking of the "responsibility of this Court as ultimate interpreter of the Constitution") (citing Baker v. Carr, 369 U.S. 186, 210-11 (1962)); Powell v. McCormack, 395 U.S. 486, 549 (1969) ("“I]t is the responsibility of this Court to act as the ultimate interpreter of the Constitution.").

113. Henry P. Monaghan, Foreword: Constitutional Common Law, 89 HARV. L. REV. 1, 27 (1975).

114. Id. at $27,29$.

115. "[Where] the will of the legislature, declared in its statutes, stands in opposition to that of the people declared in the Constitution, the judges ought to be governed by the latter, rather than the former." THE FEDERALIST No. 78, at 525 (Alexander Hamilton) (J.E. Cooke ed., 1961). This language simply states that when the legislature is out of step with the views of the people, the courts should have the authority to step in. Rather than making judges supreme over the Congress, this notion means that "the power of the people is superior to both." Id. This suggests that one guideline courts should use when borrowing from the legislature is to make sure that the legislature's view properly reflects the views of the people, and not congressional self-dealing. U.S. Term Limits, Inc. v. Thornton, 514 U.S. 779, 837 (1995).

116. THE FederaLIST No. 78, supra note 115, at 522-23. 
The authority of the proposed supreme court of the United States, which is to be a separate and independent body, will be superior to that of the legislature. The power of construing the laws according to the spirit of the constitution, will enable that court to mould them into whatever shape it may think proper; especially as its decisions will not be in any manner subject to the revision or correction of the legislative body. This is as unprecedented as it is dangerous. ${ }^{117}$

Hamilton assures people they should not worry. In the first place, judicial review is deducible from the idea of limited constitutional government. ${ }^{118}$ In the second, the Court's decisions can be corrected:

It is not true, in the second place, that the parliament of Great Britain, or the legislatures of the particular states, can rectify the exceptionable decisions of their respective courts, in any other sense than might be done by a future legislature of the United States. The theory neither of the British, nor the State constitutions, authorises the revisal of a judicial sentence, by a legislative act. Nor is there any thing in the proposed constitution more than in either of them, by which it is forbidden. In the former, as well as in the latter, the impropriety of the thing, on the general principles of law and reason, is the sole obstacle. A legislature without exceeding its province cannot reverse a determination once made, in a particular case; though it may prescribe a new rule for future cases. This is the principle, and it applies in all its consequences, exactly in the same manner and extent, to the state governments, as to the national government, now under consideration. Not the least difference can be pointed out in any view of the subject. ${ }^{119}$

Hamilton appears to suggest that the legislature can reverse the Court's decisions. He is not clear on this point, however, for he could simply be speaking to nonconstitutional decisions. At the least, it is worth noting that even the great defender of the courts, Alexander Hamilton, does not go so far as to insist upon judicial supremacy.

The most powerful defense of judicial supremacy is based on individual rights, that there are times when we want a decisionmaker insulated from the electorate. After all, the structure of the Constitution creates a "rights-protecting asymmetry" whereby the concurrence of all three branches is necessary before the government may

117. The Federalist No. 81, at 542 (Alexander Hamilton) (J.E. Cooke ed., 1961).

118. Id. at 543.

119. Id. at 545 . 
take away an individual's rights. Congress must pass a bill, ${ }^{120}$ the President must enforce it, ${ }^{121}$ and the courts must side with the constitutionality of the government's action. ${ }^{122}$ Each branch effectively can prevent a change in the status quo that deprives someone of a right. Take, for example, a powerful campaign-finance reform bill. Congress might not pass a bill it believes to be unconstitutional. Should Congress pass the bill, the President can veto it or refuse to enforce the law (or pardon those convicted under it). Finally, the courts can use judicial review to nullify it. This rights-protecting bias is a key structural feature of the Constitution. To give Congress the power to overrule court decisions that protect individual rights is to undermine this scheme by giving one branch of government the ultimate constitutional authority to take rights away from individuals.

This defense of judicial supremacy only works, however, when the Court is more protective of individual rights than Congress. Those who criticize congressional interpretation on the ground that the Court is a better protector of liberty, therefore, need to ask themselves which branch is supreme when Congress is more protective of liberty interests than the Court. Put differently, a concern for individual rights does not necessarily favor judicial supremacy. Indeed, it may cut against it. To this end, let us consider some options whereby Congress might have more responsibility for interpretation.

Option 4, judicial second-look, allows affirmative congressional action to flout a Supreme Court decision, and, in this sense, comes closer to a model based on accountability. The action is limited, and strong elements of judicial independence remain. That is because the model gives the Court the ability to disregard legislative input. In exercising this option, or any other option where Congress approaches constitutional parity with the Court, the Court should consider Congress's awareness and degree of scrutiny of the constitutional issue. ${ }^{123}$ The Court may use Congress's pronouncements to strip away the le-

120. U.S. CONST. art. I, § 7, cl. 1, 2.

121. Id. art II, $\S 3$. The President also has the power to veto a law he thinks unconstitutional, $i d$. art. I, $\S 7$, cl. 2, as well as to pardon people convicted on the basis of an unconstitutional act, id. art. II, § 2, cl. 1 .

122. Marbury v. Madison, 5 U.S. (1 Cranch.) 137, 177 (1803).

123. The modalities of congressional action can be divided into four categories: Congress may ignore the Court's views, it may try to anticipate them in cases down the road, it may seek to influence them, or it may rebel against them through principled interpretation. Congressional action to influence the Supreme Court's future pronouncements is an attractive option. It allows legislative input about a constitutional matter, but retains the judiciary's advantages of independence and settlement. 
gitimacy afforded to past decisions due to stare decisis or may take Congress's views into account in revisiting a constitutional matter.

Option 5, judicial definition/legislative implementation, permits the Court to announce a legal holding and leave the remedy up to the legislature. This adaptation of Larry Sager's brilliant article has the advantage of providing recognition to constitutional rights that are judicially underenforced. ${ }^{124}$ Courts often fear imposing remedies due to their lack of expertise and their lack of political accountability, which can lead them to water down the substantive right to sidestep the remedy question altogether. By leaving the remedy decision to the legislature, accountability for the remedy exists; at the same time, the constitutional interpreters remain insulated from ordinary politics. This is, in part, what the Connecticut Supreme Court did in Sheff v. O'Neill, where it declared the Connecticut school-financing system unconstitutional, but left the choice of remedy largely up to the legislature. ${ }^{125}$ More recently, the Vermont Supreme Court followed this path in considering the constitutionality of restrictions on gay marriage. ${ }^{126}$ Some Justices on the U.S. Supreme Court in Bush v. Gore also made a half-hearted attempt to leave the remedy to others, but a majority of the Court contorted Florida law to prevent the more accountable Florida courts (or legislature) from choosing a remedy. ${ }^{127}$

The virtues and vices of Option 6, deference, depend on its implementation. If the Court readily defers to legislative interpretation, the system evolves into a model of legislature-driven constitutionalism. If Congress can make a credible argument that a given law does not infringe a right, such as freedom of speech or religion, then this option suggests that Congress should be able to enact that law. The Court, in the face of constitutional contestability, would defer to the elected and accountable Congress. On the other hand, if the Court defers rarely and reluctantly, then the system remains a model of judicial supremacy.

124. Sager, supra note 69, at 1213-15 (describing problems arising from underenforced constitutional norms).

125. 678 A.2d 1267, 1289-90 (Conn. 1996) (holding that the separation of powers compels the court to afford the legislature, with the assistance of the executive branch, the opportunity to craft a remedy in response to constitutional violations).

126. Baker v. State, 744 A.2d 864, 886 (Vt. 1999) (holding that the state was required to extend to same-sex couples the common benefits and protections that flowed from marriage under Vermont law but allowing the legislature to choose among various constitutionally permissible remedies).

127. 121 S. Ct. $525,532-33(2000)$. 
Option 7, declaratory relief, by contrast, is designed to notify Congress of a potential constitutional violation without forcing the matter. Congress still can undertake its activity, but it does so against the explicit recognition that it is contradicting the judgment of the Supreme Court. Such an approach may be justified by the ideals underlying the Legal Process School-that Congress is accountable in ways the Court is not, and therefore the Court should not interfere with the popular will.

Option 8, congressional supremacy, is the most aggressive. Again, it derives its strength from the belief that Congress is better situated to make constitutional judgments than the Court. It ventures even further to say that courts must adhere to Congress's views. Such an approach may be necessary in cases where there is a fear that the Court will use its declaratory or advicegiving powers in ways that interfere with majority rule. There is a danger that the Court, even if it is not given a final say in constitutional interpretation, will use its lesser judicial powers to prevent Congress from enacting needed legislation. Option 8 therefore holds that the Court must back down in the face of a constitutional command from Congress.

The situations that demand congressional supremacy are quite rare. So too, few situations will demand Option 1, judicial supremacy. In the next few pages, I sketch out an intermediate option between these extremes that blends legislative and judicial interpretation. I shall demonstrate this intermediate option with a concrete example that reveals the relative importance of accountability and independence.

In Dickerson v. United States, ${ }^{128}$ the Supreme Court was asked to decide whether congressional or judicial supremacy in interpretation was appropriate. Congress had passed a statute, 18 U.S.C. $§ 3501$, to overrule Miranda. The parties in Dickerson told the Court it had two choices: either decide that $\S 3501$ was similar to the statute at issue in Boerne (and therefore impermissible) or that it was similar to the statute at issue in Palermo (and therefore permissible). ${ }^{129}$ The Boerne analogy, urged by the government and the defendant, suggested that $\S 3501$ was an improper legislative narrowing of the constitutional rights set forth by the Supreme Court. The Palermo analogy, urged by

128. 530 U.S. 428 (2000).

129. City of Boerne v. Flores, 521 U.S. 507, 517-21 (1997) (providing that the Court will be the final arbiter with respect to constitutional issues); Palermo v. United States, 360 U.S. 343, 345-48 (1959) (deferring to Congress to modify rules that are not constitutionally required). 
amicus law professor Paul Cassell, suggested that Congress has the authority to overrule judicially created rules of evidence that are not constitutionally required. ${ }^{130}$

The Supreme Court decided that $\S 3501$ could not trump Miranda, ruling in favor of judicial supremacy. The decision's final paragraph "conclude[d] that Miranda announced a constitutional rule that Congress may not supercede legislatively." ${ }^{, 131}$ The Court stated that it did not overrule Miranda because of two facts. First, the Court found that "Miranda has become embedded in routine police practice to the point where the warnings have become part of our national culture." 132 Second, the Court found that the test revived by $\S 3501$ would be too difficult for officers to apply. ${ }^{13}$

The Court in Dickerson was right to describe $\S 3501$ as a statute designed to overrule-by its own force-a Supreme Court decision. Many members of the 1968 Congress criticized the proposed bill on such grounds, ${ }^{134}$ but this contention went over like a lead balloon. Gerald Ford, then a member of the House, put it well:

130. The court below believed that it had to put $\S 3501$ into one of these two lines of cases. Dickerson, 166 F.3d 667, 687-88 (4th Cir. 1999), rev'd, 530 U.S. 428 (2000):

Whether Congress has the authority to enact Section 3501, therefore, turns on whether the rule set forth by the Supreme Court in Miranda is required by the Constitution. If it is, Congress lacked the authority to enact Section 3501, and Miranda continues to control the admissibility of confessions in federal court. See City of Boerne. If it is not required by the Constitution, then Congress possesses the authority to supersede Miranda legislatively, and Section 3501 controls the admissibility of confessions in federal court. See Palermo [citations omitted].

131. Dickerson, 530 U.S. at 437.

132. Id.

133. Id. ("But experience suggests that the totality-of-the-circumstances test which $\S 3501$ seeks to revive is more difficult than Miranda for law enforcement officers to conform to, and for courts to apply in a consistent manner.").

134. 114 CONG. REC. 16,066 (1968) (statement of Rep. Celler):

The Supreme Court has laid down the course of conduct for the police to follow.... [The Congress lays] down another course.... Who decides which is right, the Congress or the court? Many of you may say, "The Congress can decide." Well, the Congress cannot decide under our Constitution. The Supreme Court is the constitutional court. The Congress cannot be the winner in that regard.

See also S. REP. NO. 90-1097, at 88-89 (1968) (dissenting views), reprinted in 1968 U.S.C.C.A.N. 2112, 2211-12:

Section 3501(a) and (b) are squarely in conflict with the Supreme Court's decision in Miranda ... and will almost certainly be held unconstitutional. ... Simply put, Congress has the power only to expand, not to contract or abrogate these basic guarantees. The fault in the Miranda decision, if any, lies not with the Supreme Court, but with the fifth amendment itself.

see also 114 CONG. REC. 14,140 (1968) (statement of Sen. Pastore) ("I do not think it is the function of the legislative body to interpret the Constitution."); id. at 13,990 (statement of Sen. Tydings) (stating that Title II is "subject to the gravest constitutional doubts" and its provisions 
I refuse to concede... that the elected representatives of the American people cannot be the winner in a confrontation with the U.S. Supreme Court. To admit that is to admit that the American people cannot control the U.S. Supreme Court. I think the American people today must have some control and jurisdiction over the judiciary of the Federal Government. The people of America-not the courts-are the ultimate authority in America. ${ }^{13 .}$

The best argument in favor of the constitutionality of $\S 3501-$ made by Representative Ford, along with Senators McClellan, Erwin, Hollings, Stennis, Lausche, and others-was that the Warren Court had improperly amended the Constitution in the Miranda decision. ${ }^{136}$ Why should the Court be left with the power to decide whether it had erred? Instead, the decision could be made by a body with comparatively little self-interest (recall that no "law" was struck down by the Court in Miranda and that the executive branch controls prosecutions) and greater public accountability. The standard argument against congressional determinations of constitutional questionsthat Congress will self-interestedly preserve the constitutionality of its own legislation-similarly impugns the Supreme Court's ability to reconsider its previous interpretation of constitutional criminal procedure.

The argument by Representative Ford and others probably was not persuasive, constitutionally speaking, in 1968. After all, the Court, despite its self-interest and insulation from the public, still had advantages stemming from its ability to protect those without power in the political process. Giving Congress the power to overrule Miranda

"rank among the most serious and extensive assaults against the Supreme Court and the independence of the Federal judiciary in the history of our nation"); $i d$. (comparing Title II to FDR's Court-packing plan and saying it "is necessary to defeat title II ... for the same reason that it was necessary to defeat the Court-packing plan. ... It will be a victory for government of law and reason, and not of emotion and the passion of the time"); id. at 14,150 (presenting the same comparison to court packing); id. at 14,152 (statement of Sen. Magnuson) (claiming that an amendment is necessary to overrule Miranda and that "it is the duty of those of us who are Members of the legislative branch to interpret the Constitution and to act in accordance with it so that we do not pass any law which we must know is unconstitutional"); id. at 14,155 (statement of Sen. Morse) (same).

135. 114 CONG. REC. 16,073-74 (statement of Rep. Ford).

136. Id. at 13,846-47 (statement of Sen. McClellan) ("This decision was an abrupt departure from the precedent extending back to the earliest days of the Republic. ... As chosen representatives of our people we have a duty to do something about it."); see also id. at 14,139 (statement of Sen. Lausche) ("In the Miranda case the Supreme Court amended the Constitution in nonconformity with the procedure set forth in that sacred document specifying how amendments shall be made."); id. at 14,156 (statement of Sen. McClellan) ("This would not be amending the Constitution. The Constitution was amended by the Court, or, more accurately, five members of the Supreme Court ...."). 
would have meant that any number of decisions, from those protecting the right to privacy to decisions creating private property safeguards, could be overruled by the political Congress. To boot, Congress might not have been acting in the interests of the majority but rather in its own interest. Did such concerns outweigh the expected cost of giving the Court the power to rewrite the Constitution, namely the loss of public accountability and expertise?

Perhaps in 1968, but perhaps not in 2001. Recall that the Court in Dickerson made two factual determinations: First, Miranda is embedded in routine police practice and has become part of the national culture, and, second, the "totality of circumstances" test of $\S 3501$ is too difficult for police to apply in practice. There is no reason why the Court, as opposed to Congress, necessarily should have the last word on these matters. What police are doing now, and what rules are easy for them to apply, are general questions to which legislatures are better suited to provide answers. Legislatures have experts available to them and advantages stemming from their political accountability.

Viewed this way, Dickerson was right to hold the 1968 statute unconstitutional. Section 3501 was an anachronism in 2000, a statute imported from an earlier time when the factual setting was entirely different. Dickerson's conclusion does not, and should not, translate into final judicial supremacy. Congress now could pass a statute in which it finds that the factual landscape has changed in the thirty-five years between 1966 and 2001 and that the four warnings have become so ingrained in the public consciousness that they need not be constitutionally compelled any longer. Because Congress, not the Court, is best-suited to make these factual assessments, such a course of action may be an appropriate blending of congressional and judicial expertise.$^{137}$ Of course, there are reasons to permit the Court to scrutinize such findings by Congress due to concerns about individual rights, ${ }^{138}$ but these concerns are not so weighty as to give the Court carte

137. "Congress, with its vastly superior fact-gathering powers, is in a much better position than the Court to formulate standards most likely to result in a correct determination, in a given case, of the issue of voluntariness of a confession." S. REP. No. 90-1097, at 88-89 (1968), reprinted in 1968 U.S.C.C.A.N. 2112, 2133 (statement of then-California Attorney General Thomas C. Lynch); see also Turner Broad. Sys., Inc. v. FCC, 520 U.S. 180, 195 (1997) (noting that Congress "is far better equipped than the judiciary to amass and evaluate the vast amounts of data bearing upon legislative questions"); Miranda v. Arizona, 384 U.S. 436, 524 (1966) (Harlan, J., dissenting) (noting that "legislative reforms ... have the vast advantage of empirical data and comprehensive study ... [and] allow experimentation and use of solutions not open to the courts").

138. See supra notes $19,68-69,120-23$ and accompanying text. 
blanche to announce any interpretation that expands individual rights.

The Miranda case reveals the extremes. On the one hand, Americans may be stuck with an overly technical rule that lets the guilty go free (and undermines accountability), or, on the other, the Constitution's focus on individual rights may be weakened by popular sentiment if Congress could overrule the decision for any reason at all. It is these twin concerns, accountability and independence, that led to our Republican Democracy and which ultimately may lead to more constructive ways of thinking about constitutional interpretation. Again, my general view is that, structurally speaking, it is dangerous to give Congress the raw power to change the Constitution in ways that diminish individual rights. The lesson from the difficult Dickerson case, however, is that there are some areas where legislative interpretation may be appropriate even if it results in reducing individual rights.

\section{The Meaning of Section 5 of the Fourteenth Amendment}

The emphasis on individual liberty has led many scholars to reject all models of interbranch interpretation. It is worth pointing out that one form of liberty is self-rule and accountability, but the critics are right to insist on a more robust view of liberty than this simple one. In those circumstances where Congress is restricting rights, judicial supremacy has much to commend it. But what about those circumstances in which Congress is expanding rights?

This was the issue the Supreme Court faced in the Boerne case. Boerne held that even an expansion of rights by Congress was inappropriate:

If Congress could define its own powers by altering the Fourteenth Amendment's meaning, no longer would the Constitution be "superior paramount law, unchangeable by ordinary means." It would be "on a level with ordinary legislative acts, and, like other acts . . alterable when the legislature shall please to alter it." ${ }^{139}$

Last Term, in Kimel, the Court quoted this language from Boerne with approval and further stated that " $[\mathrm{t}]$ he ultimate interpretation and determination of the Fourteenth Amendment's substantive meaning remains the province of the Judicial Branch." ${ }^{140}$ Both cases

139. City of Boerne v. Flores, 521 U.S. 507, 529 (1997) (citation omitted).

140. Kimel v. Fla. Bd. of Regents, 528 U.S. 62, 81 (2000). 
are in obvious tension with the view that Congress should have interpretive power through ordinary law.

It should come as no surprise to students of economics that the Court has tried to curtail the Section 5 power. Section 5 is a threat to the Court's newfound supremacy, and, as such, the Court has tried to zap it. Just as defenders of judicial review fear the self-interested congresswoman who claims her legislation is constitutional to maximize her influence, so too should we fear the jurist who claims Congress must adhere to the Court's decisions. This is particularly so in those cases where the justification for judicial independence-individual rights-cuts against judicial supremacy because Congress is being more protective of individual rights. If Congress is seeking to broaden constitutional protections through Section $5,{ }^{141}$ independence generally will not be an important value to protect and accountability will be enhanced. Accordingly, Congress may have the ability to expand substantive constitutional values but not to restrict them, precisely because of the lowered independence concerns in the former situation. $^{142}$

A variant of this theory was put forth by Justice Brennan in Katzenbach v. Morgan, ${ }^{143}$ where he argued that Congress only has power to add to the Court's prohibitions on conduct by state governments, not the power to remove them. ${ }^{144}$ Recall that the structure of the Constitution creates a rights-protecting asymmetry in which this one-way ratchet fits nicely. ${ }^{145}$ The Constitution's text supports this one-way ratchet: when Congress believes that the Court's conception of substantive rights is too narrow - as in RFRA - it can be said to be "enforc[ing]" the Fourteenth Amendment's guarantee by enacting legislation to broaden rights. ${ }^{146}$ On the other hand, when Congress

141. I am assuming here that Congress's expansion of a constitutional right does not conflict with another constitutional right. There are some circumstances in which the Congress might believe that a right conferred by the Court is so broad under the Fourteenth Amendment that it conflicts with other Fourteenth Amendment rights. Suppose, for example, that Congress believed that the Court's Establishment Clause jurisprudence was so sweeping that it interfered with the Free Exercise Clause.

142. Some advocates of states' rights may believe any federal expansion of individual rights necessarily conflicts with the Constitution. This view is too broad a reading of the Tenth Amendment and the policy underlying it. See supra note 98 (discussing the views of Wechsler, Kramer, and Choper). In any event, this problem plagues expansions of individual rights by the judiciary at least as much as, if not more than, expansions by Congress.

143. 384 U.S. 641 (1966).

144. Id. at 651 \& n. 10 .

145. See supra notes 19, 68-69, 120-23 and accompanying text.

146. U.S. CONST. amend. XIV, § 5. 
believes that the Court's protection of substantive rights is too expansive and uses legislation to try to restrict those rights, it is not necessarily "enforc[ing]" the Fourteenth Amendment. Its goal is not to protect the Fourteenth Amendment, but rather to accomplish some other end. When Congress uses its Section 5 power to expand individual rights above and beyond that conceived by the Supreme Court, the end is to enforce the guarantee of the Fourteenth Amendment.

The theory behind this one-way ratchet is not only applicable to Section 5. Those who ground their defense of judicial supremacy on the view that the judiciary is a superior protector of individual rights must confront the fact that this defense justifies supremacy only for those cases where the Congress is less protective of rights than the Court. Where Congress is more protective, this defense of judicial supremacy vanishes. Congress ought to have a more powerful voice, and, indeed, perhaps even the power to trump the Court, in these cases. No doubt this argument will not resonate as strongly for those who believe the Constitution primarily protects the states and protects individual rights only secondarily. Even for these proponents of strong federalism, however, congressional expansions of individual rights should be preferred over judicial ones. The latter are almost entirely removed from oversight by states, the former are not. Thus, legislative constitutional interpretation to expand individual rights is an attractive model compared to the current model of judicial supremacy.

This is not to suggest that Congress should resort to the Section 5 power in the bulk of cases. The advice and consent power sketched out earlier has several advantages over legislation. First, it creates a useful mandatory waiting period. A Supreme Court decision cannot receive direct Senate input immediately. The interval between the time a law is struck down and the time of another Supreme Court confirmation hearing can be expected to encourage sobriety and candor. This delay may also reduce the possibility that a senator will take a constitutional position out of legislative self-interest. Second, it permits ex post blessings of decisions that Congress believes are correct interpretations of the Constitution-so that the conversation between the two branches does not always take the form of criticism. Statutes that call Supreme Court decisions into question can generate friction between the branches. Third, confirmation hearings are welladapted to the consideration of major questions about interpretive philosophy. They allow the Senate to give guidance about approaches and suggest courses of conduct for cases that cannot be foreseen in 
the present day. An individual statute, by contrast, speaks only to the narrow issue being decided. ${ }^{147}$ Fourth, confirmation hearings garner more attention and may attract a variety of interest groups that band together to support or oppose a particular candidate.

A final advantage of confirmation hearings, or a possible disadvantage, is that they shift the locus of power toward the states instead of to the aggregate population. Because the Senate, not the House, is responsible for confirmation, relatively unpopulous States such as Delaware, Utah, and Vermont can play a disproportionate role in such proceedings.

There are also disadvantages to using hearings in this manner. For example, their use risks long delay, and poor constitutional law may remain on the books against the consent of the governed while waiting for a vacancy on the Court. In addition, the nominations process may be a poor vehicle for constitutional debate because the personality and charisma of the nominee will skew the debate and prevent serious discussion of constitutional issues. ${ }^{148}$ Moreover, one advantage of using legislation is that Congress can pass laws that reflect constitutional principles, even when such legislation is not necessarily constitutionally compelled. A law such as $\S 1983,{ }^{149}$ which vindicates constitutional guarantees, is one such instance. Another example concerns the way Congress can pass legislation pursuant to the Republican Guarantee Clause ${ }^{150}$ to vindicate certain constitutional principles that are not judicially enforceable under current law. Hearings are not as well-adapted to accomplish these tasks.

147. On the other hand, the Senate may be geared for a constitutional question that arises in the context of ordinary legislation. Since the time of John C. Calhoun, the Senate has had a little-known rule that permits any senator to raise a constitutional point of order. RIDDICK'S Senate Procedure: Precedents AND Practices 685 (1992). Once such a point of order is called, the policy debate stops, and the entire Senate is called to vote upon the matter. Id. The Senate has not employed such a procedure in recent years, but it was used in 1971 by Senator Dole in an attempt to block certain financing of presidential election campaigns, and in 1978 Senator Hatch attempted to use it to block a proposal for a constitutional amendment permitting the District of Columbia to have senators. See 117 CONG. REC. 42,632 (1971) (statement of Sen. Dole); 124 Cong. REC. 27,249 (1978) (statement of Sen. Hatch); Interview with Robert B. Dove, Senate Parliamentarian, in Washington, D.C. (Feb. 9, 2000) (stating that the Senate has not used the procedure recently).

148. Ackerman, supra note 56, at 1180-81.

149. 42 U.S.C. $\$ 1983$ (1994).

150. U.S. CONST. art. IV, §4. 


\section{A Note on Populist Constitutional Law}

The final option discussed at the outset, Populist Constitutional Law, moves away from government institutions altogether. My thought-provoking colleague Mark Tushnet has recently proposed that populist constitutional law is appropriate for some parts of the Constitution (called the "thin" Constitution), but not others (the "thick" Constitution). The "thin" Constitution, as Tushnet describes it, is largely about the Declaration of Independence and the Constitution's "fundamental guarantees of equality, freedom of expression, and liberty." apart from the judicially created rules and jargon about them. ${ }^{152}$ What's more, he claims, these guarantees are about principles, not about giving the plain text a fixed meaning. So "all men are created equal" can be reframed as "all people are created equal," and so on. ${ }^{153}$ By "people" Tushnet means not just American people, but all the world's people. " "[I]t is a law committed to the principle of universal human rights ...." the clauses that set out how the government is to operate. ${ }^{156}$ The Opinions Clause, for example, can be put neatly into this category. ${ }^{157}$

The line between the thin and thick Constitutions, however, seems awfully thin (so to speak). Why is equality transformed into a bedrock principle of the Founding as opposed to, say, separation of powers or federalism? Those structural guarantees, it was thought, were at least as important as equality. ${ }^{158}$ Indeed, those guarantees were designed to enhance equality and liberty. The line dividing the

\footnotetext{
151. TUSHNET, supra note 67 , at 11 .

152. Id. at $9-12$.

153. Id. at 11 .

154. Id. at 53 ("If we see the Constitution and the Declaration working together, we would conclude that the people of the United States are constituted by our commitment to the realization of universal human rights, which when realized would render the community defined as 'the people of the United States' politically unimportant.").

155. Id. at 181.

156. Id. at 9 (describing the thick Constitution as containing "detailed provisions describing how the government is to be organized").

157. Id. at 9-10.

158. See THE Federalist Nos. 47-51 (James Madison) (Jacob E. Cooke ed., 1961). For example, in The Federalist No. 47, Madison notes disagreement concerning the interdependent structure of the executive, legislative, and judicial branches. He characterizes this structure as being one "in favor of liberty" and designed to "expose some of the essential parts of the edifice to the dangers of being crushed by the disproportionate weight of other parts." THE FEDERALIST No. 47, supra, at 323. As previously mentioned, there are reasons that Tushnet could use to explain why federalism is protected adequately through the political process. See supra note 98 .
} 
thin and thick Constitutions, it appears, has more to do with the author's personal preferences than with any underlying claim of what is constitutive in the American value structure. ${ }^{159}$ The idea that the Declaration of Independence and the Constitution's Preamble establish a national commitment to universal human rights seems particularly strained. It appears to be a more apt description of what Tushnet would like the Declaration and Preamble to establish. What about the Declaration's "Reliance on the Protection of Divine Providence?"160 Or the Preamble's emphasis on "domestic Tranquility" and "common defence?"161 Does the latter establish a National Security Constitution where individual rights give way to the security of the state? Even if Tushnet would permit such outcomes, his approach disregards too much of the document's text. Passages other than the isolated fragments toward which Tushnet points are just as essential to the American identity. In short, although it is appropriate to criticize the judicial appropriation of constitutional interpretation, interpretation of the entire document is still necessary, albeit perhaps with the aid of additional branches.

Instead, Tushnet converts the Constitution into a wish-list of the values he considers important today. Indeed, by defining concepts at such a broad level of generality (Tushnet transforms "all men are created equal" into something akin to a twentieth-century sermon by Martin Luther King, Jr.), we risk losing sight of what our Framers actually had in mind. Of course, Mark Tushnet has not stopped remembering the legacy of slavery and the countless other ways our Founders denied true equality to all. Even so, his constitutional prescription risks forgetting these complications in the name of some broader principle that is so amorphous and contestable as to be almost an empty vessel. Without some method of interpretation, we are left with amnesiac politics.

In any event, Tushnet's proposal differs substantially from the other options discussed in this Essay in that it envisions that the people, not the legislature, will drive constitutional interpretation. The problems with this proposal are many. Just as Publius warned of the

159. My fear that outcome drives Tushnet's theory is stoked by other parts of the book as well. For example, at several places in the book, Tushnet appears to ground his faith in populist constitutional law in his frustration with the Court's substantive decisions. "At the moment, progressives and liberals are losing more from judicial review than they are getting." TUSHNET, supra note 67 , at 72 .

160. DECLARATION OF INDEPENDENCE para. 24 (U.S. 1776).

161. U.S. CONST. pmbl. 
danger that direct democracy would turn into oligarchy, ${ }^{162}$ so too should we worry about a constitutional model based on such principles. Tushnet's approach would neglect the power that nongovernment elites possess and substitute a rosy picture in which everyone warms his hands over fires in town halls and has equal weight in deciding the meaning of "equality." Yet it is far more likely that a few elites with access to money and resources will dominate the debate. For the same reasons that unregulated campaign contributions allow some voices to drown out others, we should similarly fear a constitutional law developed by the few, for the few. ${ }^{163}$

Government actors, whether they be in Congress or the courts, have a claim and a duty to represent the people as a whole. Individuals have no such obligation at all. Given the constraints of time and resources, it is difficult to imagine that many constitutional decisions would command the attention of the public at irregular intervals of time. Instead it may be better to use elections, which provide regularized intervals, to capitalize on what Bruce Ackerman has called the "economization of virtue." "164 Thus, perversely, we could see a degradation, not an elevation, of constitutional discourse through populist constitutional law. What's more, we can expect this discourse not to be egalitarian, but a discourse in which the haves trump the havenots.

Mark Tushnet's book performs a valuable service by questioning the orthodoxy of judicial interpretation of the Constitution. We should all build on his important work in developing a suitable replacement to the orthodoxy, but we must be careful to avoid embracing a cure that is worse than the disease.

\section{IMPEACHMENT}

Impeachment provides a powerful example of legislative constitutional interpretation. Two staples of judicial interpretation, ignoring public opinion polls and following precedent, function quite differently in the setting of legislative interpretation. Even though Con-

\footnotetext{
162. See supra notes 91-93 and accompanying text.

163. Tushnet, at one point, unwittingly acknowledges this possibility. In describing the failed Bork nomination, Tushnet says that abortion rights advocates staged a "brilliant rhetorical move" in which they linked Bork's criticism of Griswold v. Connecticut to Roe v. Wade. TUSHNET, supra note 67, at 64. The upshot, Tushnet says, was that "Bork's nomination failed, and everyone learned the lesson. You had to support a constitutional right to privacy no matter what ...." Id. at 65.

164. 1 ACKERMAN, supra note 38 , at 257-59.
} 
gress sits as a court of impeachment, its institutional characteristics differ fundamentally from the Supreme Court. These differences explain why congressional interpretive methodologies may not be symmetric to judicial ones.

\section{A. The Role of the People}

Impeachment requires interpretation. It is thus one part of legislative constitutional interpretation, albeit one in which Congress has interpretive supremacy over other branches. Studying whether the method of interpretation here should be similar to the method courts use will therefore provide lessons of both specific and general applicability. When Congress determines the meaning of "other high Crimes and Misdemeanors," ${ }^{165}$ I believe that it can do what is generally unthinkable for courts to do: it can say that the text, history, and structure do not provide a clear answer, and that constitutional meaning should reflect popular views and beliefs about whether a "high Crime" has been committed.

Because Congress is institutionally situated to obtain the views of the electorate, it should use voters' views in determining the meaning of contested constitutional provisions, such as those governing impeachment. ${ }^{166}$ Even as noted a constitutional scholar as Charles Black has argued that Congress cannot listen to popular views in performing its impeachment duties. ${ }^{167}$ I disagree. Congress should take those views into account, particularly when the issue deals with a matter such as whether a President is able to do his job. In so doing, Congress must take the text, history, and structure into consideration. But it should also ask whether popular opinion bears on the question of whether the President committed an impeachable offense. ${ }^{168}$

165. U.S. CONST. art. II, $\S 4$.

166. This part intentionally extends some of the arguments in the previous part, such as those about accountability and institutional competence, to the impeachment arena. There are, however, important differences, such as the fact that impeachment is committed exclusively to Congress, see Nixon v. United States, 506 U.S. 224, 233 (1993), and that there is no risk of a conflicting interpretation among the different branches. Moreover, impeachment requires a supermajority to execute, a fact that may constrain excessive interpretations of the Constitution and mean that there is less to fear from interpretative methodologies that give more power to the Congress. See infra note 168.

167. CHARLES BLACK, IMPEACHMENT 20 (1974) ("The taking, at intervals, of public opinion polls on guilt or innocence, should be looked on as an unspeakable indecency.").

168. A standard rejoinder to this line of argument is to say that the Constitution should not insist on such anchors for judges due to legislative process failure. See ELY, supra note 97, at 7377, 101-04. The argument might be adapted to the legislative context to justify strict anchors because they will restrain the Senate from using impeachment in ways that magnify process fail- 
Popular opinion alone, however, cannot control the matter. Members of Congress cannot impeach simply because their constituents dislike the President. The text settles some questions. An impeachment must be for an activity like "treason" or "bribery." 169 The text also requires each senator to take an oath to do justice-language that would prevent a senator from voting to convict simply because his constituents want such a result. To pretend that this text predetermines an answer in all impeachment cases, though, risks hiding political motivations behind constitutional argument. ${ }^{170}$ Ap-

ures. However, it is somewhat difficult to imagine a high-level official like the President being the victim of process failure. In any event, the two-thirds requirement for a conviction, U.S. CONST. art I, § 3, cl. 6, may prevent most pernicious results, and a separate interpretive anchor therefore may not be required. As Alexander Hamilton remarked, "the concurrence of two-thirds of the senate will be requisite to a condemnation, the security to innocence, from this additional circumstance, will be as complete as itself can desire." THE FEDERALIST No. 66, at 446 (Alexander Hamilton) (Jacob E. Cooke ed., 1961); $c f$. Cong. GlobE, 40th Cong., 2d Sess. 483 (1868) (statement of Rep. Bingham) (advocating a proposal preventing the Supreme Court from striking down a statute without a two-thirds majority).

169. U.S. CONST. art. II, §4. Some, such as Luther Martin, have argued that the Framers designed the impeachment clauses to prevent one's office from being dependent on the "passions or prejudices of jurors." 3 THE RECORDS OF THE FEDERAL CONVENTION OF 1787, at 407 (Max Farrand ed., 1937) (reprinting the remarks of attorney Luther Martin, who was defending Justice Chase in the United States Senate on February 23, 1804).

170. It may be impossible to devise a system that relies exclusively on text, history, and structure. Consider the Clinton impeachment. As a matter of constitutional governance, it would seem simpler to have a world in which all the standards were laid down clearly ahead of time, so that we would know whether impeachment is a proper remedy when a President

a)

1) lies, or

2) obfuscates

b)

1) to the American people, or

2) to a court in

-direct testimony, or

-a deposition, or

3) to a friend or aide, or

4) to an aide, or

5) to a Head of State

c) about a matter that is

1) material, or

2) nonmaterial

d) in a

1) civil case, or

2) criminal case

e) that is

1) dismissed, or

2) not dismissed 
peals to text, history, and structure in this context run the risk of being dangerous and counterproductive because they may mask the role that politics plays in the process, thereby interfering with political accountability. ${ }^{171}$

It is, of course, very difficult to argue that the text, history, and structure would ever compel an impeachment. Any Republican who adhered to such a position during the Clinton impeachment risked constitutional ridicule: a senator always should have room to examine the seriousness of the offense, to assess a President's fitness for office, and to grant mercy if appropriate. What about the Democrats, who claimed that the Constitution absolutely prevented Clinton from being impeached? Are they guilty of obfuscation?

Probably. In their appeals to strict construction of the text and history, the Democrats were able to paint the decision to acquit as one not of their choosing, but of the Founders'. This is not a constitutionally ludicrous position, but it imposes a cost, the deflection of responsibility. There is, in this sense, less to fear from the Republican position, which was obviously political, than there was from the Democrats, whose constitutional position was more credible and thus more likely to distract attention from their own role in the process. My point is not to suggest that the Democrats were right or wrong in the Clinton matter. My point is that the predetermination of a constitutional matter such as impeachment can impose large costs, especially the loss of accountability. In some circumstances, that may be the Constitution's goal. The Framers did not specify impeachment for any crime but only for activities that were analogous to "treason" and "bribery." In the tough cases, where the text and history are not clear, arguments about their determinacy can dodge accountability.

There is a stronger need for transparency in the congressional context than in the judicial one. In the legislative arena, we expect

f) on a matter of

1) sexual privacy, or

2) concerning foreign affairs, or

3) concerning something else.

Simply to chart this out, of course, is to reveal the impossibility of the task-and it is worth nothing that this chart only encompasses lying and perjury, not the many other activities that could conceivably give rise to an impeachment. Clear standards are impossible: the factual permutations are too many, and the ability of language to capture them is limited.

171. Susan Low Bloch, Impeachment Inquiry Checklist, WASH. POST, Nov. 22, 1998, at C6; Letter from Law Professors Richard Abel et al. to U.S. House of Representatives, Nov. 9, 1998, available at http://jurist.law.pitt.edu/petit1.htm (on file with the Duke Law Journal). 
that politics will play a role in interpretation. ${ }^{172}$ Virtue exists in letting that role be open, unabashed, and honest. Indeed, because members of Congress are accountable to the people for their constitutional judgments in future elections, our system of government should encourage candor so that elections serve their accountability function properly. For this reason, Hamilton's answer to the critics who claimed that the Senate would be too aristocratic and unfair in impeachment trials was to suggest that senators could be voted out and thus were subject to popular control. ${ }^{173}$

Judicial interpretation, on the other hand, is not as closely intertwined with politics (nor should it be). No future election exists, and judges are insulated from the polls and popular sentiment by life tenure and salary guarantees. They are viewed primarily not as Republicans and Democrats but as impartial members of the judiciary. Indeed, there may be institutional reasons why, even if Justices act as partisans, this partisanship should not be explicitly acknowledged, to preserve the myth of impartiality and stability in the law. ${ }^{174}$ In short, transparency simply is not as important a value for unelected judges as it is for the elected Congress. The latter is accountable in ways the former are not. ${ }^{175}$

172. This theme from The Federalist Papers continues to be emphasized even today. E.g., Alison Mitchell, Senate Acquits Clinton; Perjury and Obstruction Charges Fail to Win Majority, N.Y. TIMES, Feb. 13, 1999, at A1 (discussing the partisan divide of Senate votes during the impeachment trial of President Clinton).

173. Hamilton believed that impeachments will

seldom fail to agitate the passions of the whole community, and to divide it into parties, more or less friendly or inimical to the accused. In many cases, it will connect itself with the pre-existing factions, and will inlist all their animosities, partialities, influence, and interest on one side, or on the other; and in such cases there will always be the greatest danger, that the decision will be regulated more by the comparative strength of parties than by the real demonstrations of innocence or guilt.

The Federalist No. 65, at 439-40 (Alexander Hamilton) (Jacob E. Cooke ed., 1961). He believed that the leaders of the impeachment "can hardly be expected to possess the requisite neutrality towards those, whose conduct may be the subject of scrutiny." Id. at 440 . But the Framers "thought the Senate the most fit depositary of this important trust." Id. After all, impeachment is "designed as a method of NATIONAL INQUEST into the conduct of public men." Id. And "who can so properly be the inquisitors for the nation as the representatives of the nation themselves?" Id.

174. Judges do, of course, write published opinions, and this may suggest we have less to fear from judges ex ante and ex post. Members of Congress similarly write their views into the Congressional Record and defend them on television, speeches, and in writings, but also helpfully lack Article III insulation from reprisal for their views.

175. Again, understanding constitutional interpretation through the prism of a nonjudicial interpreter also highlights other background features of our Constitution. Suppose, for example, that a President's impeachment defense were based upon a clear error and deference argument: "I believe my actions were not impeachable and this Body should defer to my constitutional 
The contrast between electorally accountable legislators and unaccountable judges implies that legislators may have room for a more expansive, less historically tethered theory of interpretation than that used by courts. Indeed, a main worry of strict constructionists, that unelected judges will usurp the democratic legislature, is inapplicable to legislative constitutional interpretation. ${ }^{176}$ Of course, this worry could be recast as one of agency costs, that members of the legislature will serve their own interests and not their constituents'. As Madison puts it in The Federalist No. 10, "Men of factious tempers, of local prejudices, or of sinister designs, may by intrigue, by corruption or by other means, first obtain the suffrages, and then betray the interests of the people." 177 At least comparatively, however, the agency cost problem is lower with Congress, which interprets the Constitution as a popularly accountable actor, than with the small and unaccountable Supreme Court. For that reason, Madison believed that the large national scope and vision of Congress would minimize the agency problem.

judgment." In this context, it is difficult to believe that this would count as a persuasive argument. Yet, why is it persuasive in the context of a Congress trying to defend its own legislation from constitutional attack in a court of law?

I suspect the reason has to do with the public-spirited nature of the defense, as opposed to the privately motivated nature of a President's defense against his own impeachment. See Veto Message of Andrew Jackson (July 10, 1832), in 2 A COMPILATION OF THE MESSAGES AND PAPERS OF THE PRESIDENTS 590 (James D. Richardson comp., 1908) (condemning the Second Bank of the United States as unconstitutional and arguing that it was passed for "selfish purposes" without adequate legislative constitutional judgment). If so, suppose that President Clinton had been impeached, not for perjury in his private civil case, but for violation of the Constitution and War Powers Resolution because of the military operations in Kosovo and Sudan. The case for deference here would be stronger because the acts at issue are not personal ones, but rather national affairs.

If one believes that deference is appropriate in the Kosovo and Sudan scenario due to this dividing line, it would follow that, when exercising judicial review, courts should cast aside deference to Congress's constitutional judgment when such judgment is not motivated by public-spiritedness. By contrast, if one thinks that deference is inappropriate due to the inherent self-dealing whenever a President defends himself against charges of impeachment based on personal conduct, then it could follow that courts exercising judicial review should not grant Congress deference to its constitutional determinations, as Congress may have a self-interest in preserving its legislation. There are, of course, institutional competence concerns involved when courts try to assess the degree of public-spiritedness-but those concerns exist as well when Congress is making such assessments. Yet one difference, again, is political accountability for those assessments, and this accountability may lead to another level of interpretive asymmetry.

176. Michael W. McConnell, Institutions and Interpretation: A Critique of City of Boerne v. Flores, 111 HARV. L. REV. 153, 189 (1997).

177. THE FEDERALIST No. 10, supra note 91, at 62.

178. Id. at 62-63 (explaining that agency costs will be minimized due to "the greater number of citizens and extent of territory" as well as the fact that "each Representative will be chosen by a greater number of citizens"). The risk of self-dealing is not, however, eliminated. Congress could use impeachment to undermine a democratically elected President, and that President 
In short, Congress might want to infuse the gaps created by text, history, and structure with popular values. The Court-despite the attempt by its Fourteenth Amendment cases to discern the history, tradition, and ideals of Americans ${ }^{179}$ - is not properly equipped to consider popular values, and it should refrain from doing so.

\section{B. The Role of Precedent}

The standard account of why judges adhere to precedent is: first, to limit the agenda of federal courts; second, to create predictability; and third, to respect the past and its indication of our values and shared history. ${ }^{180}$ Some of these reasons apply to impeachment. Predictability of impeachment standards, to the extent it is possible, allows the President and Congress to structure their affairs proactively. ${ }^{181}$ Respect for the past might be particularly important because it highlights the legitimate ways in which power is second-guessed and transferred in our Republic. The first of the three reasons to adhere

may have a claim to represent a majority of the nation's people in a way that a bare congressional majority may not. Because of district-by-district voting and other features, a Democrat can be elected President even when Congress is predominantly Republican (the 1996 election is a good example). Forcing a President to garner the approval of not just the people in an election, but also a majority of the Congress, could do serious violence to the structure of government and undermine the popular mandate given to the President. This may be one reason why the Framers insisted on a two-thirds vote for conviction in the Senate. See supra notes 166-68 and accompanying text.

179. E.g., Washington v. Glucksberg, 521 U.S. 702, 720-21 (1997) (describing the "established method" of substantive due process analysis as examining whether a particular right is manifested in "[o]ur Nation's history, legal traditions, and practices").

180. See Anthony T. Kronman, Precedent and Tradition, 99 YALE L.J. 1029, 1066 (1990) ("We must respect the past because the world of culture that we inherit from it makes us who we are."); Henry P. Monaghan, Stare Decisis and Constitutional Adjudication, 88 Colum. L. REV. 723, 748-56 (1988) (noting that judicial adherence to precedent is "defended by pointing to the important values in decisionmaking that are promoted thereby: consistency, coherence, fairness, equality, predictability and efficiency"); Frederick Schauer, Precedent, 39 STAN. L. REV. 571, 595-98 (1987) (arguing that "fairness" and "predictability" are among the most common justifications for treating precedent as relevant).

181. On the other hand, just as with the text, see supra note 170 , we may question whether it is even possible to ever come up with a sufficient set of precedents that will encompass every situation of what constitutes a "high Crime or Misdemeanor." The range of possibilities is too vast, the potential offenses too many. As House Manager Benjamin Butler put it during the impeachment trial of President Johnson, it is not possible to anticipate the "infinite gradations of human wrong and sin by which the liberties of a people and the safety of a nation may be endangered." CONG. GLOBE, 40th Cong., 2d Sess. 29 (1868). So, predictability may be elusive. What is more, predictability may be dangerous-for what counts as acceptable behavior in one generation may not be so in the next. Just think of slavery. Nevertheless, the point has some force in suggesting that the type or range of behavior that is impeachable ought to be enumerated to the extent it is possible-in the same way that abstract ideas like "due process" are given content by government actors today. 
to precedent, to limit the decisionmaker's agenda, may not be applicable if one believes that Congress should consider present values, and not be bound by past ones because of its fundamental duty to its current constituents.

It is commonly thought that precedent should not be given much credence if the precedent was based on political considerations. James Madison, for example, rejected reliance on legislative constitutional constructions as precedent when they were "adapted on the spur of occasions, and subject to the vicissitudes of party or personal ascendencies." 183 Such an argument at first blush would counsel against adherence to precedent in impeachment.

The Clinton proceedings reveal a different argument for relying on precedent. Both sides made two types of arguments from precedent—backward-looking and forward-looking arguments. Democrats looked backward to argue that the Chase, Johnson, and Nixon cases militated strongly against impeaching President Clinton. ${ }^{184}$ They also looked forward to argue that a vote to impeach the President would set a new precedent that a President could be removed for virtually any reason at all, thereby undermining popular rule. ${ }^{185}$ Republicans, on the other hand, looked backward to argue that the rules laid down in prior circumstances supported the impeachment of President Clinton. ${ }^{186}$ They also looked forward to argue that a refusal to impeach and remove Clinton would set a dangerous precedent for future Presidents. ${ }^{187}$

182. Cf. Paul W. Kahn, Gramm-Rudman and the Capacity of Congress to Control the Future, 13 HASTINGS CONST. L.Q. 185, 186 (1986) (arguing that "[c]ontrolling future legislative behavior" was the undesirable essence of the Gramm-Rudman Act).

183. Letter from James Madison to M.L. Hurlbert (May 1830), in 9 THE WRITINGS OF JAMES MADISON 1819-1836, supra note 22, at 370, 372.

184. E.g., 145 CONG. REC. S195 (daily ed. Jan. 14, 1999) (trial memorandum of President William Jefferson Clinton) ("Past Precedents Confirm that Allegations of Dishonesty Do Not Alone State Impeachable Offenses .....").

185. Id. at 196 ("To Make Impeachable Offenses of These Allegations would Forever Lower the Bar in a Way Inimical to the Presidency and to Our Government of Separated powers ....").

186. E.g., 145 CONG. REC. S1792-93 (daily ed. Feb. 23, 1999) (statement of Sen. Sessions) (arguing that prior impeachment precedents require removal of President Clinton from office).

187. Consider, for example:

What are the consequences of failing to remove this President from office if you believe he committed the crimes of perjury and obstruction of Justice? . . . First, at the very least, you will leave a precedent of doubt as to whether perjury and obstruction of Justice are high crimes and misdemeanors in impeaching the President. In fact, your vote to acquit under these circumstances may well mean that no President in the future will ever be impeached or removed for perjury or obstruction of Justice. Is that the record that you want? 
Ironically, the fact that legislative precedents can be personal and political might militate in favor of, not against, respect for legislative precedent. The reason lies in the distinction between backwardlooking and forward-looking arguments from precedent. A forwardlooking doctrine of stare decisis in the legislature, in certain contexts like impeachment, may reduce partisanship in constitutional adjudication. Republicans and Democrats have no idea who will be President in 2005 , or in 2011 , so their votes on impeachment take place behind a veil of ignorance. If the positions lawmakers take today will bind future Congresses, the present-day Congress may be less likely to act out of partisan interests. In such a circumstance, a strong stare decisis rule will encourage sobriety and evenhandedness. Therefore, it might be appropriate to adopt a rule that is the opposite of the one Madison wanted-a rule that in situations where partisanship is likely, stare decisis should be adopted - to constrain party politics in the case at hand. ${ }^{188}$

This idea, that precedent increases the cost of decision and thereby contributes to impartiality and attention to detail, may be applied to the courts as well. Instead of focusing on agenda limitation or stability, stare decisis may be justified as reducing the tendency of judges to stretch the law in a particular instance. The stare decisis doctrine puts judges on alert that their stretching in the case at hand will bind future decisions and that they lack knowledge about what those future decisions will be. This veil of ignorance counsels re-

Second, you will be establishing the precedent that the standard for impeachment and removal of a President is different from that of impeaching or removing a judge or any other official.... [F]or all times you are going to set a precedent that there is such a distinction.

Third, if you ... do not believe a President should be removed when economic times are good and it is strongly against the popular will to do so, by voting to acquit you will be setting a precedent for future impeachment trials. . . . Would our Founding Fathers have ever envisioned that? Of course not. Our Constitution was structured to avoid this very situation. ... What mischief have you wrought to our Constitution, to our system of government, to the values and principles cherished by future generations of Americans?

145 Cong. REC. S1355 (daily ed. Feb. 8, 1999) (statement of Manager McCollum).

188. A system based on precedent is, in one sense, anathema to one based on popular values, and therefore this proposal could be read to be in tension with the arguments advanced in Section III.A above. The defense of precedent in this section, however, is designed to reduce the agency costs between those who are elected and the electorate. Members of Congress are likely to be tempted by the partisan apple in ways that the general electorate is not. Adherence to precedent by the legislature in impeachment may reduce this temptation and encourage reflection on the appropriate general standard for impeachment. But precedent should give way to a present judgment by the people, should the two conflict, because doing so reduces agency costs 
straint, for a broad interpretation of the Constitution can come back to haunt a particular Justice in a later case. By increasing the costs of decision, stare decisis constrains broad, activist interpretation by a nonrepresentative decisionmaker. The corollary of this rule is that court decisions that explicitly state that the opinion's logic and rules are not binding in future cases should be disfavored because they minimize decision costs and permit party bias to creep into the judiciary. Americans were recently treated to this exact problem (in both senses of the word "party") in the recent election decision Bush v. Gore, ${ }^{189}$ where the Supreme Court expressly announced that its decision did not set a precedent for future cases. ${ }^{190}$

A separate argument for precedent has to do with economy. If an agreed-upon definition of "high Crimes and Misdemeanors" has emerged, it may be preferable to use that definition than continually to reinvent the wheel. As Representative St. George Tucker put it in 1818:

This practice-this uniform acquiescence... of the nation... on Constitutional powers ... serve as landmarks for subsequent legislatures. They are the buoys which the wisdom of the nation has fixed .... Do gentlemen suppose that if, which Heaven permit! this confederation of States shall last for a century, we shall, throughout that period, be continually mooting Constitutional points; holding nothing as decided; admitting no construction to have been agreed upon; and, instead of going on with the business of the nation, continually occupied with fighting, over and over again, battles a thousand times won? ${ }^{191}$

189. 121 S. Ct. 525 (2000).

190. Id. at 532 ("Our consideration is limited to the present circumstances, for the problem of equal protection in election processes generally presents many complexities.").

191. 32 AnNALS OF CONG. 1325 (1818). This would not counsel adherence to precedent in all circumstances; legislation "against the clear meaning of the Constitution" was of no precedential authority. $I d$. The fact that legislative precedent was considered important is also evident from the action of states in the immediate post-Founding years. For example, the Kentucky Resolutions of 1799 proclaimed compliance with the Alien and Sedition Act, but followed that proclamation with a statement:

[I]n order that no pretext or arguments may be drawn from a supposed acquiescence, on the part of this commonwealth in the constitutionality of those laws, and be thereby used as precedents for similar future violations of the federal compact- this commonwealth does now enter against them its solemn PROTEST.

The Kentucky Resolutions of 1799, in DOCUMENTS OF AMERICAN HISTORY 184 (Henry Steele Commager ed., 1958). Later, Representative Tucker remarked:

It is true, that all sorts of precedents are not to be regarded. It would be absurd to speak of the alien and sedition laws as precedents. It would be absurd to attribute the sanctity of national acquiescence, to measures which were received with the deep- 
More recently, Russell Hardin has argued that "the power to make a decision and then to get on with life rather than to keep the issue permanently open is beneficial" because it enables us "to organize ourselves for progress, rather than to dissipate our energies in random directions." ${ }^{192}$ This argument can cut in favor of greater deference to precedent by Congress than by the courts. Unlike the courts, which have as their central role the definition and exposition of the Constitution, Congress has other important and weighty duties, from passing a budget to securing domestic tranquility. In light of its many responsibilities, it may be helpful to settle on a definition of "high Crimes" so that Congress need not consume itself with lengthy deliberations. ${ }^{193}$

A somewhat different account of adherence to legislative precedent stresses humility. Because individual members of Congress might not feel comfortable believing they have found the one correct interpretation of the Constitution, they should at times look for guidance to interpretations by those who preceded them. ${ }^{194}$ This was the argument James Madison made in resolving his doubts about the con-

toned murmurs of national disapprobation.

32 ANNALS OF CONG. 1326 (1818).

192. Russell Hardin, Why a Constitution?, in THE FEDERALIST PAPERS AND THE NeW INSTITUTIONALISM 100, 116 (Bernard Grofman \& Donald Wittman eds., 1989); see also Jon Elster, Introduction to CONSTITUTIONALISM AND DEMOCRACY 1, 9 (Jon Elster \& Rune Slagstad eds., 1988) ("[I]f nothing could ever be taken for granted, there would be large deadweight losses arising from bargaining and factionalism.”).

193. Others, such as Fred Schauer, have argued that these concerns are applicable in the judicial context as well. Schauer, supra note 180, at 599 (observing that adherence to precedent can conserve "the decisional resources of the decisionmakers" by avoiding the "reconsideration of questions already considered").

194. Consider, in this light, Representative Butler's strong plea in 1850 that Congress has the power to prohibit slavery in the territories:

The power over slavery in the territories has the authority of precedent to sustain it.... This power has been exercised, repeatedly exercised-from the time of the formation of the Constitution, and by the very men who framed that instrument-always claimed and used whenever thought necessary, until this moment. Sir, this is precedent of the highest kind; it is precedent to which we ought to defer; and if the [Representative who claims otherwise] had been a judge upon the bench deciding ... he would have deferred to the authority. I admit we are not absolutely bound to follow in legislation the precedents and practice of those who have gone before us, but they should always be respected....

I am content to be guided in this respect by the light shed upon my path by the wisdom and patriotism of those who have gone before me, believing that as long as I have the authority and illumination of their example, and that of many of the greatest intellects of the present day, I cannot be far astray.

Cong. Globe, 31st Cong., 1st Sess. 762 (1850). 
stitutionality of the Bank of the United States. ${ }^{195}$ Such concerns are exacerbated when Congress is not representing the people's interest, but rather its own, in impeachment. It may have been the case, for example, that the popular President Clinton was being impeached not because the American people wanted that result, but because the Republican party wanted it. ${ }^{196}$ In circumstances where Congress does not speak for the people through its views about impeachment, it may be better for the body to adhere to longstanding precedent instead of its personal beliefs about the Constitution's meaning. Doing so reflects the view that even if no one entity can legitimately speak for the people at any given time, the cumulative weight of successive speakers is imbued with as democratic a character as possible.

195. In 1791, Congressman James Madison opposed the Bank, largely on constitutional grounds, but Congress chartered the Bank for twenty years. 2 ANNALS OF CONG. 1960 (1791). When the charter expired, a vote in Congress to renew the Bank failed when Vice President Elbridge Gerry voted against it in the Senate. 22 AnNALS OF CONG. 346-47 (1811). In 1815, a bill to renew the Bank passed both houses. President Madison was confronted with the question of whether to assent to its constitutionality. Madison vetoed the bill, but his veto was confined to policy grounds. His veto message opened by "[w]aiving the question of the constitutional authority of the Legislature to establish an incorporated bank" because such a question was "precluded in my judgment by repeated recognitions under varied circumstances of the validity of such an institution in acts of the legislative, executive, and judicial branches of the Government, accompanied by indications, in different modes, of a concurrence of the general will of the nation." James Madison, Veto Message to the Senate of the United States (Jan. 30, 1815), in 8 THE Writings OF JAMES MADISON 327 (Gaillard Hunt ed., 1908).

As Madison would later explain, the "charge of inconsistency between my objection to the constitutionality of such a bank in 1791 and my assent in 1817, turns on the question how far legislative precedents, expounding the Constitution, ought to guide succeeding Legislatures and overrule individual opinions." Letter from James Madison to Charles J. Ingersoll (June 25, 1831), in 4 LETTERS AND OTHER WRITINGS OF JAMES MADISON, supra, at 183, 183-84. The Bank had received "the entire acquiescence of all the local authorities, as well as of the nation at large; to all of which may be added, a decreasing prospect of any change in the public opinion adverse to the constitutionality of such an institution." Id. at 186 . To veto the bill under these circumstances would be "a defiance of all the obligations derived from a course of precedents amounting to the requisite evidence of the national judgment and intention." Id. Madison believed that his own "abstract opinion of the text," Letter from James Madison to C.E. Haynes (Feb. 25, 1831), in 4 LETTERS AND OTHER Writings OF JAMES MADISON, supra, at 164, 165, could not prevail against "a construction put on the Constitution by the nation, which, having made it, had the supreme right to declare its meaning," Letter from James Madison to General de La Fayette (Nov. 1826), in 3 LETTERS AND OTHER WRITINGS OF JAMES MADISON, supra, at 538, 542. "I did not feel myself, as a public man, at liberty to sacrifice all these public considerations to my private opinion." Id. For those interested in presidential interpretation, Madison's focus on the "nation's" views suggests a difference between the national constitutional vision of Presidents and what may be a more localized view by members of Congress.

196. John J. Miller, No Need to Hide, N.Y. TIMES, Feb. 18, 1999, at A21. 


\section{CONCLUSION}

We have taken a journey through some recent constitutional tribulations - the impeachment of President Clinton, the decisions about the constitutionality of RFRA and $\S 3501$ - to demonstrate that the ways in which Congress interprets the Constitution can and should differ from the ways in which the Court does. There are arguments for and against the use of popular values in interpretation, but many of those arguments depend on who is doing the interpreting. Likewise, there are arguments for and against stare decisis, but their validity will depend on factors such as the representational quality of the interpretive body and the specific matter at hand. Rather than resolving these questions, my goal has been to show a range of appealing combinations that constitutionalists could profit from exploringcombinations that blend the advantages of accountability with those of independence.

Having the Court adhere to strict construction of the text, history, and structure of the Constitution, while Congress makes determinations about contemporary values, might yield a better balance between the anachronism and countermajoritarian problems than does pure strict construction. Congress would perform a dualist role by reflecting on constitutional values at critical moments and applying those values to present-day situations. The constitutional tapestry will, of course, become even more intricate when the third branchthe executive-is factored into the equation. ${ }^{197}$

The twentieth century was, in many ways, a struggle between the branches for constitutional supremacy. The courts quietly won, and this victory came with costs. Interbranch interpretation provides one

197. In making such claims, I have not considered what type of interpretation is appropriate for the executive branch. In some ways, the arguments here about Congress will mirror those for the President-such as the comparative accountability of the President vis-à-vis the Supreme Court. In substantial respects, they differ as well. Accountability of the President for any given constitutional interpretation is quite weak due to the large number of issues that may influence an election. Because the President is only one person, he is susceptible to capture in a way that Congress may not. Once the question of agencies-which have expertise but perhaps not as much accountability (but see Jerry L. Mashaw, Prodelegation: Why Administrators Should Make Political Decisions, 1 J.L. ECON. \& ORG. 81, 95-99 (1985))—are factored into the picture, the matter requires a much more in-depth treatment.

Nevertheless, envisioning combinations of three different actors, with a multiplicity of interpretive methodologies, may yield intriguing and important results. (Imagine, for example, if the Court adhered to strict construction, the Congress focused on making the Constitution square with popular mores, and the President played the role of a moral philosopher about the Constitution.) The possibilities for three-branch asymmetry is a promising line of future research, but one not developed in this initial Essay. 
[Vol. 50:1335

way to minimize these costs and redraw the lines in favor of more accountable constitutional decisionmaking. Within this possibility lies the seed of a theory of constitutional interpretation that harnesses the benefits of strict construction and simultaneously permits the Constitution to evolve as the events of our great nation unfold. 